\title{
Measuring and modeling the spectrum of fine-root turnover times in three forests using isotopes, minirhizotrons, and the Radix model
}

\author{
Julia B. Gaudinski ${ }^{1,2,3^{*}}$, M.S. Torn ${ }^{2}$, W.J. Riley ${ }^{2}$, T.E. Dawson ${ }^{3}$, J.D. Joslin ${ }^{4}$, H. Majdi ${ }^{5}$ \\ ${ }^{1}$ Department of Environmental Studies, University of California Santa Cruz, Santa Cruz, CA USA \\ ${ }^{2}$ Earth Science Division, Lawrence Berkeley National Laboratory, Berkeley, CA, USA \\ ${ }^{3}$ Department of Integrated Biology, University of California Berkeley, Berkeley, CA USA \\ ${ }^{4}$ Belowground Forest Research, Apartado 104-5655, Monteverde, Puntarenas, Costa Rica \\ ${ }^{5}$ Deceased, December 2007. Formerly at the Department of Ecology, Swedish University of \\ Agricultural Sciences, Uppsala Sweden
}

*Author to whom correspondence should be addressed: (email: jbgaudinski@gmail.com) 


\section{Abstract}

Fine root $(<2 \mathrm{~mm})$ cycling rates are important for understanding plant ecology and carbon fluxes in forests, but they are hard to determine and remain uncertain. This paper synthesizes minirhizotron and isotopic data and a root model and concludes that (1) fine roots have a spectrum of turnover times ranging from months to many years and (2) the mean age of live root biomass $(A)$ and the mean age of roots when they die (i.e., their turnover time $(\tau)$ ) are not equal.

We estimated $A$ and $\tau$ of fine roots in three forests using the root model Radix. For short-lived roots, we constrained $\tau$ with existing minirhizotron data; for long-lived roots, we used new radiocarbon measurements of roots sampled by diameter size class and root branch order. Long-lived root pools had site mean $\tau$ of 8-13 y and 5-9 y when sampled by diameter and branch order, respectively. Mean turnover times across sites were in general not significantly different as a function of branch-order, size class, or depth. Our modeling results indicate that $\sim 20 \%$ of fine root biomass has turnover times of about a year, and $\sim 80 \%$ has decadal turnover times. This partitioning is reflected in our predicted mean ages of $\sim 9 \mathrm{y}$ and turnover times of $\sim 3 \mathrm{y}$. We estimate that fine root mortality contributes between 38 and $104 \mathrm{~g} \mathrm{C} \mathrm{m}^{-2} \mathrm{y}^{-1}$ to soil in these forests. These estimates are 20 to $80 \%$ of previous estimates in these and similar forests, in part because we explicitly account for the large portion of fine-root biomass with decadal cycling rates. Our work shows that both fast and slow cycling roots must be modeled jointly to account for the heterogeneous nature of fine-root dynamics.

\section{Introduction}

A large fraction of carbon (C) assimilated by forest ecosystems is allocated to the growth and maintenance of "fine roots" $(<2 \mathrm{~mm}$ diameter $)$; the most dynamic part of the root population 
[Hogberg et al., 2002; Hogberg et al., 2001]. Total belowground C allocation in turn may be respired as $\mathrm{CO}_{2}$, stored in live-root biomass, or input to the soil system as organic $\mathrm{C}$ via root exudation, sloughing, and mortality. New-root production and the flux of live-root tissue to soil organic matter (SOM) via root mortality are two large, yet very uncertain, fluxes in ecosystem carbon budgets.

Based primarily on many sequential coring studies and more recent minirhizotron data, fine roots were thought to have mean lifetimes of about one year [Gill and Jackson, 2000]. Thus, fine roots are typically modeled as one pool with fast turnover times [Parton et al., 1998; Thornton et al., 2007]. The result is that root mortality is estimated to be a very large C flux to soils (e.g., $33 \%$ of net primary productivity (NPP) globally [Jackson et al., 1997]). However, two studies measuring ${ }^{14} \mathrm{C}$ (bomb- ${ }^{14} \mathrm{C}$ approach [Gaudinski et al., 2001]) and ${ }^{13} \mathrm{C}$ (Free-air $\mathrm{CO}_{2}$ Enrichment [Matamala et al., 2003]) in root tissues concluded that a significant portion of fine-root mass lives for 5 to more than $10 \mathrm{y}$. These findings were corroborated by additional isotopic studies in different forest types [Joslin et al., 2006; Keel et al., 2006; Trumbore et al., 2006; Vargas et al., 2009] and by a direct comparison of minirhizotron and ${ }^{14} \mathrm{C}$ techniques [Tierney and Fahey, 2002].

The 10-fold difference between root ages estimated by minirhizotron and isotopic techniques reveals an essential characteristic of root demography. Namely, each technique measures a different end of the broad spectrum of root turnover times, ranging from months to decades [Gaudinski et al., 2001; Guo et al., 2008c; Hogberg and Read, 2006; Pritchard and Strand, 2008; Strand et al., 2008; Tierney and Fahey, 2002]. Since roots have a wide distribution of turnover times, and since C fluxes through the fine-root system depend on these distributions, ecosystem C-cycling models need to incorporate these findings to accurately characterize $\mathrm{C}$ dynamics through plants and into SOM. 
Nevertheless, there has been little change in root production and mortality models since the 1970s [Majdi, 2005], and many ecosystem models still use a one-pool approach (e.g., [Parton et al., 1998; Thornton et al., 2007]). Specifically, most ecosystem models determine a single turnover time for all root biomass below a cutoff diameter. Literature discussions of possible approaches to modeling heterogeneity in root turnover-times have focused on addition of skewed distributions of turnover time and/or at least two pools to represent fine roots (fast and slow) [Guo et al., 2008c; Hogberg and Read, 2006; Joslin et al., 2006; Majdi, 2005; Tierney and Fahey, 2002; Trumbore and Gaudinski, 2003]. However, to our knowledge, Riley et al. [2009] provide the only study applying these approaches to modeling field data and estimating fine-root production. We apply that numerical model (Radix) here.

A population of fine roots with heterogeneous ages implies that the mean age of live-root biomass $(A)$ and the mean age of roots when they die (i.e., their turnover time $(\tau)$ ) are not equal [Trumbore et al., 2006]. These two parameters are generally assumed to be equal [Gaudinski et al., 2001; Trumbore and Gaudinski, 2003], but actually are equal only if the root population is in steady state and each root in the population has the same probability of death [Rodhe, 1992]. Yet minirhizotron observations suggest all roots do not have the same probability of death [Tierney and Fahey, 2002; Wells and Eissenstat, 2001] and that root function, metabolism rates, and probability of death likely change with root age [Pregitzer et al., 2002; Wells and Eissenstat, 2003]. Thus, root age distribution may affect rates of respiration, exudation, resource use, and $A$ and $\tau$. Consequently, to better understand root ecophysiology and to accurately model ecosystem carbon cycling, we need to characterize both $A$ and $\tau$.

Traditionally, field studies involving manual separation of fine roots, sampled from soil cores, have used diameter size class as a proxy for separating roots of different cycling rates [Pregitzer et 
al., 2002]. Although more time consuming, sampling by position on the root branch system is another option employed by several recent studies [Guo et al., 2004; Guo et al., 2008a; Guo et al., 2008b; Wang et al., 2006]. Root branching structure is a key characteristic of root systems and governs both root form and function [Fitter, 2002]. First- and second-order roots (the most distal portions of the root system; Figure 1) differ in anatomy and nutrient and cellulose content relative to higher order roots [Guo et al., 2004; Guo et al., 2008b; Pregitzer, 2003; Pregitzer et al., 2002] and cycle more quickly than less distal (i.e., higher) branch orders for a given root system[Wells and Eissenstat, 2003].

The goal of our study was to advance modeling and sampling techniques for predicting belowground $\mathrm{C}$ fluxes. In three different forest types (temperate conifer, temperate deciduous, and boreal conifer), we used a multi-pool root growth model to (1) determine the mean age of live fineroot biomass and the turnover time of fine roots based on mortality; (2) estimate new root production and $\mathrm{C}$ fluxes from roots to soil organic matter (SOM) via root mortality; and (3) assess the relative utility of root diameter size class and branch order as methods of separating roots of different turnover times.

To accomplish these three objectives, we combined ${ }^{14} \mathrm{C}$ observations of fine roots, extant minirhizotron data (from the same or very similar sites), and Radix [Riley et al., 2009]. We used the minirhizotron data to estimate turnover times [Hendrick and Pregitzer, 1992] for the short-lived root pool and ${ }^{14} \mathrm{C}$ measurements of fine roots to estimate a turnover time (bomb- ${ }^{14} \mathrm{C}$ approach; Figure 2; [Gaudinski et al., 2001]) for the long-lived root pool. Using these turnover times and observed fine-root biomass, we estimated the proportion of root biomass that is short- vs long-lived and the annual input of root-derived C to SOM from mortality. 


\section{Methods}

\section{Study Sites}

Our three study sites spanned a range of forest types, and each site had relevant minirhizotron data. Harvard Forest is a mixed deciduous forest in central Massachusetts $\left(42.54^{\circ} \mathrm{N}, 72.18^{\circ} \mathrm{W}\right)$. The forest has been regrowing undisturbed since being leveled by a hurricane in 1938. The dominant tree species in the study area are northern red oak (Quercus rubra L.) and red maple (Acer rubrum) with some hemlock (Tsuga canadensis Carr.) and white pine (Pinus strobes L.). The Blodgett Experimental Forest (Blodgett Forest) is a mixed conifer forest in the central Sierra Nevada, California $\left(38.53^{\circ} \mathrm{N}, 128.30^{\circ} \mathrm{W}\right)$. The area was logged around 1920 and most trees are $60-80$ years old. The dominant species is ponderosa pine (Pinus ponderosa Laws), with intermixed white fir (Abies concolor Lind. \& Gord.), douglas fir (Pseudotsuga menziesii (Mirb.) Franco), and incense cedar (Calocedrus decurrens (Torr.) Florin). Knottåsen is a conifer forest located near the Jädraås experimental station in central Sweden. The study area $\left(61.00^{\circ} \mathrm{N} 16.13^{\circ} \mathrm{E}\right)$ was clear-cut in 1963 and planted in 1965, primarily with 2-year-old Norway spruce (Picea abies (L.) Karst.) seedlings and secondarily with Scots pine (Pinus sylvestris L.). Complete climate and soil information for each site can be found in Gaudinski et al. [2009].

\section{Field and Laboratory}

\section{Local Atmospheric ${ }^{14} \mathrm{CO}_{2}$ Records}

Although previous studies relied on hemispheric records of atmospheric ${ }^{14} \mathrm{CO}_{2}$ as model input [Gaudinski et al., 2001; Tierney and Fahey, 2002; Trumbore et al., 2006], hemispheric ${ }^{14} \mathrm{CO}_{2}$

records do not account for local influences of fossil fuel and respired $\mathrm{CO}_{2}$. We therefore used a local 
atmospheric ${ }^{14} \mathrm{CO}_{2}$ record as input, generated from annual tree ring data and direct atmospheric measurements for each study site, according to methods detailed in [Gaudinski et al., 2009]. Because a longer tree ring record is important for the Radix modeling here and potentially to other researchers working at these sites, we present here the tree ring ${ }^{14} \mathrm{C}$ content of cellulose sampled in a ponderosa pine at Blodgett Forest (1976-2004), northern red oak at Harvard Forest (1951-2003), and Norway Spruce at Knottåsen (1972-2003) and results for flask measurements of local air for Harvard Forest (2001), Knottåsen (2001 and 2002), and Blodgett Forest (2002 and 2003).

\section{Collection and Processing of Roots from Soil Cores}

Soil cores were collected at each site for root biomass and isotopic measurements. Core location method, core diameter, and sampling depth intervals for each site are shown in Table 1. Once sampled, cores were kept cool and transported to the University of California, Berkeley, or the University of California, Santa Cruz, where they were frozen or kept at $4^{\circ} \mathrm{C}$ until processed. To simplify discussion across sites, we refer to the four sampled soil horizons as the $\mathrm{O}$ horizon, mineral 1, mineral 2, and mineral 3. The total profile depth sampled at Harvard Forest, Blodgett Forest, and Knottåsen was 25,30 , and $60 \mathrm{~cm}$, respectively.

For mineral soil, roots were separated from soil by carefully rinsing samples over three stacked sieves, which from top to bottom were $2 \mathrm{~mm}, 0.5 \mathrm{~mm}$, and $0.25 \mathrm{~mm}$ mesh [Joslin et al., 2006]. All roots $>4 \mathrm{~mm}$ in length and $\leq 2 \mathrm{~mm}$ diameter were removed from the screens and sorted into five diameter size classes ( $<0.3 \mathrm{~mm}, 0.3$ to $<0.5 \mathrm{~mm}, 0.5$ to $<0.8 \mathrm{~mm}, 0.8$ to $<1.1$, and 1.1 to $<2 \mathrm{~mm}$ ), using calipers, and then separated into live and dead categories (see Joslin et al. [2006] for further details). Live roots were distinguished from dead roots based on tensile strength, integrity, and color of the vascular tissue [Joslin et al., 2006; Ostertag, 2001; Vogt and Persson, 1991]. If there was doubt as to whether a root was live or dead, we categorized it as "dead" to ensure that ${ }^{14} \mathrm{C}$-derived 
turnover times for live roots were from roots we were certain were live. Roots from non-woody, non-dicot species, such as grass (at Knottåsen) or ferns (at Harvard Forest), were removed from the samples. Organic horizon samples were not washed through screens; rather, roots were separated from the $\mathrm{O}$ horizon material using forceps. Once separated into size class and live or dead categories, samples were oven-dried $\left(50^{\circ} \mathrm{C}\right.$ for a minimum of 48 hours $)$, weighed, and ground using a Spex Certprep 8000 M Mixer Mill to a fine homogeneous powder (5-15 minutes).

At Blodgett Forest, there was abundant new growth visible at the root tips (i.e., very light color and unsuberized). Therefore, at this site only, we sorted roots as described above but also separated out these new roots. We measured the mass and ${ }^{14} \mathrm{C}$ of these roots separately and then corrected and reported the mass and ${ }^{14} \mathrm{C}$ contents as if the roots had not been removed (the $\Delta^{14} \mathrm{C}$ value used in the correction was either sample-specific or an average value based on seven samples).

\section{Collection and Processing of Roots by Branch Order}

To measure $\Delta^{14} \mathrm{C}$ as a function of branch order, we collected 7-9 intact root segments from a dominate tree species at each site (Table 1) near where soil coring took place. We did not estimate biomass or root length by branch order. Samples were collected by first identifying a large root $(>5$ mm diameter) from red maple (Harvard Forest), ponderosa pine (Blodgett Forest), or Norway spruce (Knottåsen). These species' roots are associated with ectomycorrhizal fungi. The root was followed until it branched and then (1) all laterals within a $300 \mathrm{~cm}^{2}$ area and to a depth of $20 \mathrm{~cm}$ below the top of the $\mathrm{O}$ horizon were extracted very carefully with forceps, in an intact segment in the field, or (2) an intact block of soil also $\sim 300 \mathrm{~cm}^{2}$ and $20 \mathrm{~cm}$ deep was removed from the field and intact root segments removed in the lab. Each root segment or intact soil block was transported and stored like the soil cores. In some cases, multiple intact segments were collected from a block dissected in the lab. 
Intact root segments were dissected by branch order, following the method described by Pregitzer et al. [2002]. Briefly, the most distal roots (i.e., root tips) are attached to second-order roots and second-order roots are attached to third-order roots analogous to stream order (Figure 1). During processing, all live portions of the intact root segment were kept moist using deionized water, separated by root order, counted, and measured for diameter in $0.1 \mathrm{~mm}$ increments with an ocular micrometer mounted on a 10X stereomicroscope (Leica Microsystems S6E). The segments were oven-dried at $50^{\circ} \mathrm{C}$, weighed, and ground as above.

\section{Determination of $\Delta^{14} \mathrm{C}$ Values}

In contrast to non-structural carbon (e.g., carbohydrates, sugars, and lipids), structural carbon (e.g., cellulose) in roots is not replaced over the life of the root [Barbour et al., 2004; Farquhar et al., 1997; Sternberg et al., 1986]. To measure the carbon from the original root growth, we removed non-structural $\mathrm{C}$ compounds and isolated cellulose via the Jayme-Wise soxhlet extraction process, followed by bleaching to operationally defined holocellulose [Gaudinski et al., 2005]. However, in 22 of 252 cases, bulk tissue was analyzed because the sample was too small to pre-treat. (e.g. $<4$

$\mathrm{mg}$ ). Nine live-root samples run with and without soxhlet pretreatment showed that the $\Delta^{14} \mathrm{C}$ values of soxhlet-treated samples were $4 \pm 2 \%$ higher than the non-pre-treated samples. Because this difference is similar to the analytical error of our accelerator mass spectroscopy (AMS) measurements (4-6\%), we did not correct the bulk sample data before combining with data from pretreated roots.

To measure root ${ }^{14} \mathrm{C}$ content, samples were combusted to $\mathrm{CO}_{2}$ in the presence of $\mathrm{CuO}$, and the $\mathrm{CO}_{2}$ was cyrogencially purified [Gaudinski et al. [2009]]. Radiocarbon results are expressed as $\Delta^{14} \mathrm{C}$, including a correction of sample $\delta^{13} \mathrm{C}$ value of $-25 \%$. This correction removes the effects of mass-dependent isotopic fractionation, such as photosynthetic discrimination [Stuiver and Polach, 
1977]. The $\delta^{13} \mathrm{C}$ values used to calculate $\Delta^{14} \mathrm{C}$ were measured for each sample on a split of the purified $\mathrm{CO}_{2}$.

\section{Statistical Analysis of Experimental Data}

Patterns in root biomass with site, depth interval, and diameter size class within a site (Table 1) were analyzed using univariate ANOVA and Tukey's post-hoc analysis. A pairwise analysis was also performed for the diameter and branch-order $\Delta^{14} \mathrm{C}$ data for all sites. Additionally, regression lines were fit to the $\Delta^{14} \mathrm{C}$ data from soil cores as a function of diameter by sites and depths and for each root segment sampled by branch order as a function of both branch order and mean diameter (i.e., mean diameter of a given branch order for all orders measured). For the soil cores, the five diameter size classes are identified using the upper value in the range (that is, as $0.3,0.5,0.8,1.1$ and $2 \mathrm{~mm}$, respectively). For branch-order samples, separate values are identified using either branch order or the mean diameter of the branch order. A student's T test (1 sample assuming known value, i.e., from wood) was used to test for significant differences between $\Delta^{14} \mathrm{C}$ measured in local air versus tree ring samples in all years where we had air samples. Results are reported as significant if $\mathrm{p} \leq 0.05$. Analyses were performed with SYSTAT 10.2. All reported errors are standard error of the mean.

\section{Modeling}

\section{Characterizing Turnover Time and Fine-Root Ages}

We used two metrics of root carbon dynamics: mean age $(A)$ and turnover time $(\tau)$ (Supplemental Information (SI) Figure 1). $A$ is the mean age of all fine-root biomass in a pool and was calculated as the biomass-weighted turnover time across the distribution of turnover-times represented within the pool. $\tau$ relates root biomass to carbon fluxes and is calculated here as the 
flux-weighted age of roots leaving the live root pool via mortality at steady state. We assumed root biomass is in an annual steady cycle (i.e., annual new root production is equal to annual root mortality flux), therefore $\tau$ is equivalent to the mean age of carbon leaving the pool and its residence time [Rodhe, 1992].

$A$ and $\tau$ are equivalent for a single well-mixed pool at steady state in which all constituents have an equal probability of mortality, as is the case for donor-controlled loss [Rodhe, 1992]. However, because younger roots are more likely to die than older roots [Tierney and Fahey, 2002; Wells and Eissenstat, 2001], fine roots likely have a right-skewed population age distribution. As a result, the $A$ and $\tau$ of a root population are not equivalent (SIFigure 1a). In this study, we imposed a lognormal distribution on $\tau$, thereby creating many component pools (i.e., a distribution of turnover times) within each of our two fine-root pools i.e., $L_{1}$ or $L_{23}$; SI Figure $1 b$ ). Each of these component pools is modeled as donor-controlled. In the case of a lognormal distribution, $A$ will be larger than $\tau$ [Rodhe, 1992]. We note $A$ and $\tau$ will differ for any distribution that is not is not symmetric or has more than one peak.

\section{Numerical Model (Radix)}

Radix is a numerical, multi-pool model of fine-root growth, mortality and decomposition (Radix 1.0; [Riley et al., 2009; Gaudinski et al. 2009], Figure 3). Radix differs from most previously published fine-root models in that it accounts for variation in fine-root turnover times, use of stored carbon [Carbone et al., 2007; Czimczik et al., 2006; Gaudinski et al., 2009; Luo, 2003; Pregitzer, 2002; Schuur and Trumbore, 2006; Vargas et al., 2009], and autotrophic respiration. Briefly, Radix simulates: (1) short-lived (months to year) and long-lived (years to decades) roots, each with rightskewed age populations; (2) stored-C and ${ }^{14} \mathrm{C}$ inputs to root growth and respiration; (3) seasonal 
variation in root respiration and growth rates; (4) structural versus nonstructural $\mathrm{C}$ in long-lived fine roots; (5) autotrophic respiration; and (6) uncertainty in forcing variables and model parameters.

At each site we used values of median longevity from site-specific minirhizotron data or literature values (Table 2 ) to estimate a turnover time for the short-lived root pool $\left(\tau_{L 1}\right)$, and ${ }^{14} \mathrm{C}$ measurements of fine roots sampled by depth and size class or branch order to determine the longlived root-pool turnover time $\left(\tau_{L 23}\right)$. The distribution of turnover times in a given root pool is represented with a lognormal right-skewed distribution with geometric standard deviation (GSD) of 2 (SI Figure 1b). The turnover time distributions are truncated to within a factor of three of the geometric mean (GM). We report best-fit turnover times in three ways: (1) biomass-weighted age of the truncated distribution $\left(A_{L 1}\right.$ or $\left.A_{L 23}\right)$; (2) flux-weighted turnover time of the truncated distribution ( $\tau_{l l}$ or $\tau_{l 23}$ ); and (3) geometric mean reported only in SI (see SI for more complete methods and equations). Previous publications using Radix reported only the GM [Gaudinski et al., 2009; Riley et al., 2009].

Roots grow from photosynthate that was either recently fixed (i.e., within the current growing season) or stored from previous growing seasons. In a deciduous forest in Oak Ridge, TN, new root growth is made up of $\sim 55 \%$ stored $\mathrm{C}\left(f_{s}\right)$ with , mean age, $\tau_{s}$, of $0.7 \mathrm{y}$ [Gaudinski et al., 2009]. For the three forest sites studied here, Gaudinski et al. [2009] concluded that storage C is less than 2 years in mean age. Therefore, we parameterized growth from storage in Radix with the deciduous oak forest data: $f_{s}=0.55$ and $\tau_{s}=0.7 \mathrm{y}[$ Riley et al., 2009].

Root respiration rates at each site were estimated as seasonal averages from site-specific relationships (See Table 2 for temperature means during each of these "seasonal periods."). At Harvard Forest and Knottåsen, the respiration equations were derived from direct measurements of respiration on roots $0.5-2 \mathrm{~mm}$ diameter [K. Savage personal communication; [Widen and Majdi, 
2001]]. The equation used at Blodgett Forest derives from measurements of respiration on roots primarily $<0.5 \mathrm{~mm}$ in diameter [Burton et al., 2002]. We assumed the observed respiration was from autotrophic respiration of recently fixed carbon, however, it may have contained some heterotrophic mycorrhizal respiration. Radix does not explicitly include flux derived from exudates or mycorrhizal fungi. Instead, these fluxes are assumed to be included in the observed root (rhizosphere) respiration flux.

Root respiration rates can vary as much as 2.4-3.4 times as a function of diameter [Pregitzer et al., 1998]. Using respiration rates from Burton et al., [2002] led to unrealistically high predictions of $R_{23}$. We therefore decreased the respiration rate for the long-lived roots $\left(R_{23}\right)$ by $66 \%$ after personal communication with A.J. Burton. Similarly, we increased the respiration rate by $66 \%$ for the $L_{1}$ roots at Harvard Forest and Knottåsen, because this pool is theoretically more representative of the types of roots measured by [Burton et al., 2002]. Table 2 lists the observed, un-scaled respiration rates.

Belowground carbon allocation (BCA) is defined as all $\mathrm{C}$ used for fine-root growth, respiration, and exudation (equivalent to BGPP in Riley et al., [2009]). We define belowground net primary production (BNPP*) of fine roots as the annual increment of new fine root biomass, meaning it excludes exudates and carbon export to mycorrhizal fungi [Clark et al., 2001; Hanson et al., 2003]. Because we assumed fine roots were in steady state on an annual time scale (though not at any one point in time), BNPP* is equivalent to the annual flux of carbon from live fine roots to dead roots and SOM.

Root turnover time and mean age for long-lived roots $\left(A_{L 23}\right.$ and $\left.\tau_{L 23}\right)$, and site average BCA and BNPP* were estimated using a two-step approach [Gaudinski et al., 2009; Press et al., 1989; Riley et al., 2009]. This approach finds the parameter values that result in the minimum absolute 
difference between model predictions and measured observations, weighted by measurement uncertainty. In the first step, using only ${ }^{14} \mathrm{C}$ data as a constraint, we determined the best-fit $A_{\text {L23 }}$ and $\tau_{L 23}$ for the long-lived roots. Then, in a second model run, we used this best-fit value of $\tau_{L 23}$ and the measured live root biomass to estimate the proportion of biomass in the $L_{1}$ vs. $L_{23}$ pools and the best-fit BCA. We then estimated BNPP* by subtracting predicted total annual respiration from BCA. Finally, we used Radix to estimate the mean behavior of pools $L_{1}$ and $L_{23}$ combined (i.e. $T_{L 123}$ or $\left.A_{L 123}\right)$. This method was applied separately for data sampled by diameter size class (and depth) and branch order for fine roots.

\section{Results}

\section{Field and Laboratory}

\section{Local Atmospheric $\Delta^{14} \mathrm{CO}_{2}$}

At all three sites, tree ring cellulose values were different than the Northern Hemispheric (NH) bomb- ${ }^{14} \mathrm{C}$ record of Levin and Hesshaimer [2000] for 1950-1976 and [Levin and Kromer, 2004] for 1977-2003 (Figure 2). However, the annual rate of decrease between 1995 and 2002 at our three sites $\left(5 \pm 1 \% 0 \mathrm{y}^{-1}\right)$ and those of Levin $\left(5 \pm 2 \% \mathrm{y}^{-1}\right)$ were nearly identical.

The influence of stored $\mathrm{C}$ reserves on the ${ }^{14} \mathrm{C}$ of new annual growth was not detectable (e.g., there were no significant differences between air and tree ring samples at any site; SI Table 1; Isotope Data Appendix). We used the local tree ring record as the recent atmospheric $\Delta{ }^{14} \mathrm{C}$ record at each site because it integrates over an entire growing season, whereas the local air samples record discrete time points. In summary, atmospheric ${ }^{14} \mathrm{CO}_{2}$ data used for ${ }^{14} \mathrm{C}$ atmospheric inputs to Radix were: (1) global background [Levin and Hesshaimer, 2000] at Harvard Forest from 1890 to 1950, Blodgett Forest from 1890 to 1975, and Knottåsen from 1890 to 1972; and (2) local tree ring data 
(Figure 2) at Harvard Forest from 1950 to 2003, Blodgett Forest from 1976 to 2004, and Knottåsen from 1972 to 2003.

\section{Roots sampled from Soil Cores}

The total oven-dried mass of fine roots was $1413 \pm 105,912 \pm 209$, and $1198 \pm 114 \mathrm{~g} \mathrm{~m}^{-2}$ for Harvard Forest, Blodgett Forest, and Knottåsen, respectively (SI, Figure 2). Live-root biomass was 40,43 , and $49 \%$ of the total, respectively (i.e., $562 \pm 38,391 \pm 77$, and $584 \pm 48 \mathrm{~g} \mathrm{~m}^{-2}$ ). However, live- and dead-root biomass were significantly different only at Harvard Forest $(p=0.007)$. At all three sites, the $<0.3$ or 0.3 to $0.5 \mathrm{~mm}$ size class had the largest mass (SI Figure 3). In fact, live + dead root biomass $<0.5 \mathrm{~mm}$ in diameter constituted 59,37 , and $45 \%$ of total root biomass at Harvard Forest, Blodgett Forest, and Knottåsen, respectively. Newly grown roots at Blodgett accounted for $6 \pm 1 \%$ of the total live biomass. In the $<0.3 \mathrm{~mm}, 0.3$ to $<0.5 \mathrm{~mm}, 0.5$ to $<0.8 \mathrm{~mm}$, 0.8 to $<1.1$, and 1.1 to $<2 \mathrm{~mm}$ size classes, newly grown roots comprised $0.1 \pm 0.1,7 \pm 3,15 \pm 2,4 \pm 2$, and $1 \pm 1 \%$ of live biomass, respectively.

\section{Roots Sampled by Branch Order}

A total of 9,723 individual root pieces were dissected from 26 intact root segments at the three sites (SI Table 2). There were up to seven orders per root segment, and average diameter of all orders ranged from 0.29 to $2.89 \mathrm{~mm}$. Diameter increased with branch order in all cases at Blodgett and Knottåsen, but not at Harvard Forest, where $1^{\text {st }}$ order roots had larger diameters than $2^{\text {nd }}$ and $3^{\text {rd }}$ order roots and $1^{\text {st }}$ and $4^{\text {th }}$ order roots were similar. Mean diameter was $>2 \mathrm{~mm}$ at Harvard Forest, Blodgett Forest, and Knottåsen in orders 5-7. Percentage of biomass in the first five orders increased by order at all sites; orders $1-3$ comprised 5 to $18 \%$ of total biomass, and orders 45 comprised 12 to $60 \%$ of total biomass. 


\section{$\Delta^{14} \mathrm{C}:$ Roots sampled from Soil Cores}

The $\Delta^{14} \mathrm{C}$ values of root cellulose were significantly higher than those of the concurrent local atmosphere. Specifically, $\Delta^{14} \mathrm{C}$ values for almost all soil core samples $(\mathrm{n}=158)$ were elevated relative to local atmospheric $\Delta^{14} \mathrm{CO}_{2}$ by more than three times the AMS analytical error (i.e., 18\%o) and more than three times the annual rate of decrease in atmospheric ${ }^{14} \mathrm{CO}_{2}$ over the time period of this study (Figure 4; Isotope Data Appendix).

The $\Delta^{14} \mathrm{C}$ values for fine root cellulose sampled at Harvard Forest in 2001 ranged between 76 and $286 \%$, with an average of $150 \pm 5 \%$ o $(n=59)$. Local tree ring wood cellulose $\Delta^{14} \mathrm{C}$ (our proxy for atmospheric $\Delta^{14} \mathrm{CO}_{2}$ ) for the same year was $80 \%$. At Blodgett Forest, in 2002, fine-root cellulose ranged from 45 to $375 \%$, with an average of $149 \pm 8 \%(n=56)$. The local value for wood cellulose at Blodgett Forest in 2002 was 62\%o, and all but three samples were elevated relative to this value by $18-312 \%$. At Knottåsen, in 2001, fine-root cellulose ranged from 69 to 213\%o, with an average of $134 \pm 4 \%$ o $(n=43)$. The local value for wood cellulose at Knottåsen in 2001 was $82 \%$, and all but two samples were elevated relative to this value by $18-130$

Linear regression of all ${ }^{14} \mathrm{C}$ values as a function of size class for a given site and horizon gave $R^{2}$ values between 0.000 and 0.479 (Table 3$)$. There were significant correlations $(p<0.05)$ in the $O$ horizon at Blodgett Forest and Knottåsen and in the mineral 1 horizon at Harvard and Blodgett Forests. Pair-wise comparisons showed no significant differences in $\Delta^{14} \mathrm{C}$ values between consecutive diameters for any site and depth. We found significant relationships between fine-root $\Delta^{14} \mathrm{C}$ values and diameter at Blodgett Forest, depth at Harvard Forest, and diameter plus depth at Harvard Forest (Table 3).

Newly grown roots at Blodgett Forest were 66 to $79 \%$ lower in $\Delta^{14} \mathrm{C}$ compared to roots of the same depth and diameter that did not appear to be newly grown (SI Figure 4). 


\section{$\Delta^{14} \mathrm{C}:$ Roots Sampled by Branch Order}

The $\Delta^{14} \mathrm{C}$ values for fine-root cellulose from $75 \%$ of the branch-order samples $(\mathrm{n}=57)$ were elevated relative to local atmospheric $\Delta^{14} \mathrm{CO}_{2}$ by more than three times the analytical measurement error. The $1^{\text {st }}$ and $1^{\text {st }}+2^{\text {nd }}$ order roots were less elevated than higher orders, with site-specific mean $\Delta^{14} \mathrm{C}$ values $7-23 \%$ above local atmospheric $\Delta^{14} \mathrm{C}$, while higher orders (2-7) had site-specific mean $\Delta^{14} \mathrm{C}$ values elevated by 25-105\%o (Figure 5; Isotope Data Appendix).

Linear regressions between $\Delta^{14} \mathrm{C}$ values and branch order within individual root segments had $\mathrm{R}^{2}$ values that ranged from 0.360 to 0.997 and were significant for all five root branch segments at Blodgett Forest, and three out of five root segments at Knottåsen (Table 3). At Harvard Forest, where samples were composited from three root segments along the same transect (instead of individual root segments) the $\mathrm{p}$ values for the regressions were not significant $(0.111$ or 0.198$)$. When all branch order samples for a site were analyzed together, correlations between $\Delta{ }^{14} \mathrm{C}$ values and branch order were significant for Blodgett Forest and Knottåsen $(\mathrm{p}=0.042$ and 0.010 ,

respectively). The linear regression between $\Delta^{14} \mathrm{C}$ and branch-order diameter approached statistical significance for ponderosa pine at Blodgett Forest $(p=0.071)$, but were not significant for red maple at Harvard $(\mathrm{p}=0.962)$, nor for Norway spruce at Knottåsen $(\mathrm{p}=0.773)$.

\section{Variability in Site-Mean $\Delta^{14} \mathrm{C}$ Values}

Within each site, size class, and depth interval $(n=3$ or 4$)$, standard errors of measured fine root $\Delta^{14} \mathrm{C}$ values ranged from 5-31, 5-80, and 3-42\%o at Harvard Forest, Blodgett Forest, and Knottåsen, respectively. At Harvard Forest and Knottåsen the standard error of samples from the O horizon tended to be lower than for the mineral horizons, ranging from 6-10\%o and 3-20\%o, respectively. The standard error for branch order samples by site and order $(\mathrm{n}=2$ to 5$)$ ranged from 8-17, 8-47, and 8-13\%o at Harvard Forest, Blodgett Forest, and Knottåsen, respectively. 
There were few significant differences in $\Delta{ }^{14} \mathrm{C}$ values across the three sites for samples sorted by size class or branch order, regardless of how means were compared. With respect to size-class sorting, we examined the site means (1) for all depths and size classes combined; (2) by depth and size class; and (3) by size class only. We found significant differences only for $<0.3 \mathrm{~mm}$ roots in the mineral 2 horizon between Harvard Forest and Knottåsen $(p=.034)$ and in the $\mathrm{O}$ horizon for roots $0.3-<0.5 \mathrm{~mm}$ between Blodgett Forest and Harvard Forest $(\mathrm{p}=0.001)$. With respect to branch order, we found no significant differences in site means for (1) all data or (2) as a function of branch order.

\section{Root Model (Radix)}

\section{Age and Turnover Time of Short-Lived Roots: Minirhizotron Data}

The estimated age of roots leaving the short-lived root pool $\left(\tau_{L l}\right)$ for each site and depth, based on minirhizotron data, ranged from 314-650 days (Table 2). The mean age of biomass within the short-lived root pool $\left(A_{L 1}\right)$ ranged from 452 to 956 days (Table 3 footnotes). We used the predicted biomass distribution resulting from the assumed right skewed turnover time distribution in each pool (e.g. $\left.L_{I}\right)$ to calculate the mean age $\left(A_{L I}\right)$ of roots in that particular pool (see SI). Because the distribution is always the same, $A_{L 1}$ is always $47 \%$ greater than $\left(\tau_{L 1}\right)$.

\section{Age and Turnover Time: Diameter Size-Class Data}

Radix estimates of long-lived fine-root turnover times $\left(\tau_{L 23}\right)$ by diameter size class were 2 to $\geq 15$ $\mathrm{y}$ (Table 4). At Harvard Forest, $\tau_{L 23}$ values were fastest in the $\mathrm{O}$ horizon (5-7 y) and slower in the mineral 1 and 2 horizons $(8-\geq 15 \mathrm{y})$. At Blodgett Forest, predicted $\tau_{L 23}$ values were variable in the $\mathrm{O}$ horizon ( $2-\geq 15 \mathrm{y})$. The mineral 1, 2 and 3 horizons had values ranging from $6-\geq 15$ years.

Knottåsen had the least variation in predicted $\tau_{L 23}$ of all three sites, with values from 5 to $11 \mathrm{y}$ in all horizons. Similar to the $\Delta^{14} \mathrm{C}$ data, predicted $\tau_{L 23}$ values tended to increase with diameter size class 
(especially in the $\mathrm{O}$ and mineral 1 horizon) with depth at Harvard Forest and Blodgett Forest and with branch order at all sites. The mean age of roots $\left(A_{L 23}\right)$ in the $L_{23}$ pool ranged from 3 to $\geq 22 \mathrm{y}$. Similar to the relationship between $A_{L 1}$ and $\tau_{L 1}, A_{L 23}$ is always $47 \%$ older than its respective $\tau_{L 23}$ value.

We also estimated dynamics for the short- and long-lived root pools combined (i.e. $L_{123}$ ), in a given size class and depth, by calculating $A_{L 123}$ and $\tau_{L 123}$ from the $L_{1}$ and $L_{23}$ components weighted by site-specific measured fine-root biomass. $\tau_{L 123}$ ranges from only 2 to $5 \mathrm{y}$ at all sites for all depths, while $A_{L 123}$ ranges from 2 to 18 y (Table 4$)$. The site average $\tau_{L 123}$ and $A_{L 123}$ values, respectively, were 4 and $10 \mathrm{y}$ at Harvard Forest, 4 and $14 \mathrm{y}$ at Blodgett Forest, and 3 and $8 \mathrm{y}$ at Knottåsen.

\section{Age and Turnover Time: Branch-Order data}

The range in $\tau_{L 23}$ values based on ${ }^{14} \mathrm{C}$ values of roots sorted by branch order ranged from 2 to 6 $\mathrm{y}$ at Harvard Forest, 3 to $11 \mathrm{y}$ at Blodgett Forest, and 2 to $5 \mathrm{y}$ at Knottåsen (Table 4). The mean age of roots $\left(A_{23}\right)$ in the $L_{23}$ pool again were all $47 \%$ larger then there respective $\tau_{L 23}$ value and ranged from 3 to $16 \mathrm{y}$, varying by site and branch order. For the short- and long-lived root pools combined, $\tau_{L 123}$ values ranged from only 2 to $4 \mathrm{y}$ across all sites, while $A_{123}$ ranged from $2-12 \mathrm{y}$. The site average $\tau_{L 123}$ and $A_{L 123}$ values, respectively, were 3 and $6 \mathrm{y}$ at Harvard Forest, 3 and $10 \mathrm{y}$ at Blodgett Forest, and 3 and $5 \mathrm{y}$ at Knottåsen.

To have a consistent number of root branch orders across all three sites, and because mean diameter is typically $>2 \mathrm{~mm}$ after the fifth order (SI Table 2), we calculated $\tau, A$, BCA, and BNPP* for the first five orders. When we excavated the branch-order roots, they tended be in the O horizon and top $20 \mathrm{~cm}$. Therefore, to estimate a contribution to the total soil profile biomass from each individual branch order, we multiplied the total biomass for the site (from soil cores) by the percent of biomass in each order (first five orders). 


\section{Belowground C Fluxes}

We estimate that at Harvard Forest, Blodgett Forest, and Knottåsen, the long-lived $L_{23}$ pool accounted for 78,84 , and $77 \%$ of the biomass, and 29,16 and $25 \%$ of BNPP* respectively, when we use $\Delta^{14} \mathrm{C}$ data from roots sampled by diameter and 78,80 , and $73 \%$ of the biomass, and 37,11 and $36 \%$ of BNPP* respectively when we use $\Delta^{14} \mathrm{C}$ data from roots sampled by branch order. The actual values in $\mathrm{g} \mathrm{m}^{-2} \mathrm{y}^{-1}$ for each determination are shown in Table 5. Radix estimates of BCA were 152,139 , and $205 \mathrm{~g} \mathrm{C} \mathrm{m}^{-2}$ respectively when calculated using $T_{L 23}$ values derived from roots sampled by diameter and 171,178 , and $244 \mathrm{~g} \mathrm{C} \mathrm{m}^{-2}$ respectively with branch-order $\Delta^{14} \mathrm{C}$ data. Branch-order sorting resulted in larger BNPP* and BCA values, because the $\Delta^{14} \mathrm{C}$ values tended to be lower, generating faster $\tau_{L 23}$ values (Table 4). Across sites, the BCA and BNPP* values were fastest at Knottåsen, which had the largest biomass and fastest $\tau_{L 23}$ values, and smallest at Blodgett Forest, which had the smallest biomass and slowest $\tau_{L 23}$ values.

\section{Discussion}

\section{Fine-Root Turnover-Time Estimations}

In the three forest types studied here, $\Delta^{14} \mathrm{C}$ values for roots sampled by soil cores and branch orders were significantly elevated relative to concurrent atmospheric $\Delta^{14} \mathrm{CO}_{2}$ (Figures 4 and 5). The extent to which the root radiocarbon values exceeded concurrent atmospheric values can only be explained with decadal-scale turnover times (Figure 6, Table 4), even when growth from stored C is taken into account. However, the minirhizotron results show that some fraction of the fine roots in every size class or branch order are born and die within one year (Table 2). Radix includes both these fast (annual) and slow (decadal) cycling root pools. If all roots were modeled with a fast turnover (e.g., $\left.\tau_{L 1}=\tau_{L 23}=0.8 \mathrm{y}\right)$, then the model predictions do not match the fine-root ${ }^{14} \mathrm{C}$ observations (Figure 6). 
Across sites, the cycling of the long-lived root pool (for all depths and size classes) is fastest at Knottåsen $\left(\tau_{L 23}=10 \mathrm{y}\right)$ and Harvard Forest $\left(\tau_{L 23}=12 \mathrm{y}\right)$ and slowest at Blodgett Forest $\left(\tau_{L 23} \geq 15 \mathrm{y}\right)$. However, there were few significant differences in mean $\Delta{ }^{14} \mathrm{C}$ values, regardless of sampling method. This inconsistency between apparently large differences in inferred $\tau_{L 23}$ and non-significant differences in $\Delta{ }^{14} \mathrm{C}$ values resulted because our method to infer $\tau_{L 23}$ (1) did not explicitly propagate model uncertainty; (2) did not account for the uncertainty in measured $\Delta{ }^{14} \mathrm{C}$ or ; and (3) has lower sensitivity to constrain the value of $\tau_{L 23}$ above about $10 \mathrm{y}$ (discussed below). For these reasons, we are unable to assess the significance of the differences in estimated $\tau_{L 23}$ and $A_{L 23}$ values among sites. Fine-root turnover times in mature tropical forests also appear to be similar to those reported here for temperate and boreal forests [Trumbore et al., 2006; Vargas et al., 2009].

We used Radix to characterize the mean cycling rates of an entire fine-root population (e.g., all roots for a given site or a given depth and size class at a site, combined in one pool) by calculating $A_{L 123}$ (the mean age of roots in the $L_{1}$ plus $L_{23}$ pools) and $\tau_{L 123}$ (the mean age of all roots leaving the $L_{1}$ plus $L_{23}$ pools via mortality). For roots sampled by size class, $A_{L 123}$ was 10,14 , and 8 years at Harvard, Blodgett, and Knottåsen, respectively, while $\tau_{L 123}$ was 3 , 4, and 3 years, respectively. In summary, the mean age of fine roots in the three forests we studied ranged from 8 to $14 \mathrm{y}$, while the turnover time was 3 to $4 \mathrm{y}$. The 5-10 year difference between $A_{L 123}$ and $\tau_{L 123}$ values clearly shows that for roots $<2 \mathrm{~mm}$ in diameter, the mean cycling rates were dominated by the $\tau_{L I}$ pool, while the mean age of the biomass was dominated by the $\tau_{L 23}$ pool. The $\tau_{L 123}$ value represents the fluxweighted mean of two pools with very different cycling rates and likely does not represent the average behavior of individual fine roots. 


\section{Characterization of Uncertainty in the Turnover Time of Long-Lived Roots $\left(\tau_{L 23}\right)$}

The $\tau_{L 23}$ values reported here ( $\left.2-\geq 15 \mathrm{y}\right)$ represent time spent after root formation because we took into account the use of stored carbon to grow roots (see methods). Even if there is error in our storage estimation based on data from Oak Ridge Tennessee, we know the age of storage $\mathrm{C}$ used to grow new roots in these forests is $<2 \mathrm{y}$ based on data from [Gaudinski et al., 2009] and the fact that $\Delta{ }^{14} \mathrm{C}$ values of new roots from Blodgett Forest were similar to atmospheric values and had mean ages $<1-2$ years (SI Figure 4 ). To investigate the sensitivity of $\tau$ to $C$ stored up to 2 years, we ran Radix with storage turnover time estimates ranging from zero to $2 \mathrm{y}$ for the mineral 1 horizon at Harvard Forest. The nominal Radix parameterization is that the fraction of annual root growth coming from storage $\left(f_{s}\right)$ is 0.55 and the age of this stored $\mathrm{C}\left(\tau_{\mathrm{s}}\right)$ equals 0.7 y [Gaudinski et al., 2009]. When no storage use was assumed (i.e., $f_{s}$ and $\tau_{s}=0$ ), best-fit $\tau_{L 23}$ values were either unchanged or less than nominal $\tau_{L 23}$ values by $1 \mathrm{y}$. When storage was assumed to be 2 y (i.e., $f_{s}=$ 0.55 and $\tau_{\mathrm{s}}=2$ ), $\tau_{L 23}$ values were either unchanged or increased by 1 y (except in one out of 15 cases, where they increased from 12 to $\geq 15 \mathrm{y}$ ).

Fine-root dynamics are sensitive to respiration rates [Riley et al., 2009]. We investigated the sensitivity of predicted $\Delta{ }^{14} \mathrm{C}$ values to assumed respiration rates and found that if respiration were not included (i.e., assumed to be zero), predicted $\Delta{ }^{14} \mathrm{C}$ values were greater by $\sim 25 \%$, which is equivalent to an increase in $\tau_{L 23}$ of $\sim 5$ yrs. When respiration rates were halved or doubled, predicted $\Delta{ }^{14} \mathrm{C}$ values changed by $\sim 10 \%$ ( $\left.\sim \pm 2 \mathrm{y}\right)$. Thus, accurately representing respiration rates is important for accurately predicting root dynamics. If respiration is omitted or underestimated, an important turnover mechanism for ${ }^{14} \mathrm{C}$ is underestimated, and $\tau_{\text {L23 }}$ will be overestimated [Riley et al., 2009].

Sensitivity of predicted fine-root $\Delta{ }^{14} \mathrm{C}$ values is not constant across the range of possible values of $\tau_{L 23}$ (Figure 6). During the time period of our study, for example, for $\tau_{L 23}$ of 11 and 17 years (6- 
year difference), predicted $\Delta^{14} \mathrm{C}$ values differed by $10 \%$ or less between 1997 and 2003. In contrast, for $\tau_{L 23}$ of 4 and $8 \mathrm{y}$ (4-year difference), predicted $\Delta^{14} \mathrm{C}$ values differed by at least $40 \%$. The sensitivity is greatest for $\tau_{L 23}$ between 2 and $9 \mathrm{y}$, where, for each year of change in $\tau_{L 23}$, predicted $\Delta{ }^{14} \mathrm{C}$ changes 5 to $8 \%$. Sensitivity declines rapidly for $\tau_{L 23} \geq 10 \mathrm{y}$. The change in predicted $\Delta{ }^{14} \mathrm{C}$ per year for $\tau_{L 23}$ between $10-12,13-15$, and $>15 \mathrm{y}$ is $\sim 3, \sim 1$, and $<1 \%$ respectively. This lack of ability to constrain long turnover-time estimates is true for Radix or simpler one-pool exponential models [Gaudinski et al., 2001]. Because of this limitation in sensitivity, we truncated all $\tau_{L 23}$ predictions to a maximumof 15 y (all such values are indicated by " $\geq 15$ " in Table 4 to indicate this limitation).

We examined the sensitivity of predicted $\tau_{L 23}$ to the observed variability in size-class sample ${ }^{14} \mathrm{C}$ values. Using Harvard Forest as an example, for each of three ranges in $\tau_{L 23}(2-9,10-12$, and 13-15 y), we performed simulations for each depth and size class (15 cases), using the measured fine-root $\Delta{ }^{14} \mathrm{C}$ (1) mean, (2) mean $+\mathrm{SE}$, and (3) mean - SE. The $\pm \mathrm{SE}$ altered predicted $\tau_{L 23}$ by $0-2$, $1-3$, and $0-3 \mathrm{y}$, for the three $\tau_{L 23}$ ranges respectively. Predicted changes for the upper $\tau_{L 23}$ range are likely larger than $3 \mathrm{y}$ but we cannot distinguish between $\tau_{L 23}>15 \mathrm{y}$.

\section{Fine-Root Production}

Characterization of belowground productivity is critical for estimating $\mathrm{C}$ balance in soils.

Our site-average estimated BNPP* values were 31, 25, and 69\% lower than published estimates of fine-root production for Harvard Forest, forests similar to Blodgett Forest and Knottåsen, respectively [Kleja et al., 2008; Law et al., 2003; McClaugherty et al., 1982] (Table 5). We likely obtained smaller estimates for two reasons. First, we are explicitly accounting for the large portion of fine-root biomass ( $\sim 80 \%)$ with decadal turnover times, whereas these previous estimates had only one pool of roots. Using one live-root pool with a fast turnover time can accurately predict 
measured biomass, but will overestimate fine-root production (and thus BNPP*) [Riley et al. [2009]. Second, these studies used roots of different diameter ranges. The previous studies for Harvard Forest and Blodgett Forest included roots $>2 \mathrm{~mm}$ in diameter. The study at Knottåsen only used roots $<1 \mathrm{~mm}$ in diameter.

Our estimated BCA values at Harvard Forest, Blodgett Forest, and Knottåsen range between 139 and $244 \mathrm{~g} \mathrm{Cm}^{-2} \mathrm{y}^{-1}$ (Table 5). These are substantially lower than BCA estimates made for the same or similar forests. For example, at six deciduous forests in the eastern United States, BCA ranged between 610 and $1120 \mathrm{~g} \mathrm{Cm}^{-2} \mathrm{y}^{-1}[$ Curtis et al., 2002; Fahey et al., 2005] based on $\mathrm{C}$ budget approaches. Our BCA estimates are sensitive to the assumed root respiration rate and include only respiration and growth from roots $<2 \mathrm{~mm}$ in diameter. Therefore, it is reasonable that they are lower than estimates from $\mathrm{C}$ budget approaches, which use measurements of total soil respiration flux, including respiration by larger roots and assumptions about the mix of heterotrophic versus autotrophic respiration. Our model estimates of BCA do not explicitly include exudates and use of recently fixed $\mathrm{C}$ by mycorrhizal fungi. Instead, these fluxes are implicitly included in root respiration rates. Radix estimates of fine-root BCA could be improved by improved quantification of fine-root respiration rates and exudation fluxes.

Our estimates of BCA and BNPP* based on branch-order sampling assumed that branch-order samples from the $\mathrm{O}$ and mineral 1 horizons applied to the total profile at each site. This assumption may introduce positive bias at Harvard Forest, where there was a significant trend of increasing $\Delta{ }^{14} \mathrm{C}$ values with depth (Table 3 ).

Our estimate that 5 to $18 \%$ of fine-root biomass is in the first three branch orders is considerably smaller than published literature values, where first- plus second-order roots typically comprise $\sim 30 \%$ or more of total live biomass [Guo et al., 2004; Wang et al., 2006] (SI Table 2). It is easy to 
undercount small and fragile first- and second-order roots. Therefore, we tested the possible impact of underestimating biomass of the smallest roots by calculating BCA and BNPP* using a published biomass distribution of $17,12,19,18$, and $34 \%$ for orders $1-5$, respectively, for a longleaf pine as a representative species [Guo et al., 2004]). The predicted increases in BNPP* of 4-17 $\mathrm{g} \mathrm{C} \mathrm{m}^{-2} \mathrm{y}^{-1}$

and BCA of 4-24 $\mathrm{g} \mathrm{C} \mathrm{m}^{-2} \mathrm{y}^{-1}$ due to increasing the percentage of biomass in the lower order, faster cycling roots were small relative to the differences between our estimates and those previously predicted.

\section{Impact of Root Partitioning Approach: Size Class versus Branch Order}

The correlation of diameter size class or branch-order with root ${ }^{14} \mathrm{C}$ content is a measure of how well these approaches separate roots with different cycling rates. We found a correlation between $\Delta{ }^{14} \mathrm{C}$ values and both diameter size class and position on the root branch (Table 3), showing that either approach can be effective. Direct comparison of the two approaches must be done with care, however, because the soil cores represented composite samples of mixed species, while branchorder samples were from a single species and, except for Harvard, were not composites. Because branch order samples came from the $\mathrm{O}$ and mineral 1 horizon, we limited our comparisons to these horizons.

Root $\Delta{ }^{14} \mathrm{C}$ values in the $\mathrm{O}$ and mineral 1 horizons had a significant trend with diameter size class in 4 out of 6 cases (Table 3), with $\mathrm{R}^{2}$ ranging from 0.290 to 0.479 for the significant cases. The ${ }^{14} \mathrm{C}$ of branch-order samples on individual root segments was significantly correlated with branch order in 8 out of 10 cases with $\mathrm{R}^{2}$ ranging from 0.360 to 0.997 for the significant cases. At Harvard, where samples were a composite of three root segments, correlations were not significant, though the $R^{2}$ values $(0.474$ and 0.626$)$ were higher than any of the $R^{2}$ values for significant 
correlations of diameter data. The fact that the branch order was a better predictor of ${ }^{14} \mathrm{C}$ value for individual root segments than for composites is consistent with the wide range in ${ }^{14} \mathrm{C}$ values between different root segments (Figure 5). Indeed, the regression on all branch-order data for a given site combined, had lower $\mathrm{R}^{2}$ values.

Thus, branch order correlates strongly and fairly consistently with root $\Delta^{14} \mathrm{C}$, especially within individual root segments. The physical basis for this correlation is that more distal roots on the root branch system necessarily are younger than the feeder roots from which they grow (Figure 1). Our observation of fast cycling $1^{\text {st }}$ and $2^{\text {nd }}$ order roots ( $\tau_{L 23}$ of $2-4 \mathrm{y}$; which represent a small total mass) with slower cycling higher-order roots ( $\tau_{L 23}$ of $4-11 \mathrm{y}$; which represent a larger portion of the mass) corroborates the idea that it is the first- and second-order roots that are cycling rapidly via cycles of birth and death from a long-lived stem [Pregitzer et al., 2002], rather than entire root segments (comprising $1^{\text {st }}-5^{\text {th }}$ orders, for example) cycling quickly. It is also consistent with the generally held notion that minirhizotrons observe primarily $1^{\text {st }}$ and $2^{\text {nd }}$ order roots.

We found a significant relationship between diameter size class and $\Delta^{14} \mathrm{C}$ in the $\mathrm{O}$ (Knottåsen, Blodgett) and mineral 1 horizons (Harvard, Blodgett; Table 3), but with low explanatory power. Patterns in fine-root diameter vary with species [Guo et al., 2008b], so mixed-species samples might be expected to have poorer correlations between diameter size class and $\Delta^{14} \mathrm{C}$ than singlespecies samples. To investigate this, we examined the relationship between $\Delta^{14} \mathrm{C}$ values and mean root diameters within the single species branch order samples. There was a relationship only for ponderosa pine $(\mathrm{p}=0.071)$ at Blodgett Forest (Figure 5). Nevertheless, the new roots sampled from mixed species soil cores at Blodgett Forest, primarily first- and second-order roots, all had $\Delta^{14} \mathrm{C}$ values similar to the atmosphere, regardless of diameter size class (SI Figure 4). Therefore, at least in the case of fresh ectomychorrizal root tips, we have direct evidence that diameter does not 
correlate with cycling rate. However ponderosa pine is the only species in which we do see a trend between $\Delta{ }^{14} \mathrm{C}$ and diameter in the branch-order samples. Thus, ectomychorrizal root tips, which represent only a small mass of the total, may be an exception.

Our results suggest that the efficacy of diameter-size-class sorting to isolate roots of different cycling rates may vary as a function of the dominant species. Branch order, on the other hand, because it is based on root physiology, structure and growth patterns, is more likely to separate roots with different cycling rates, regardless of species and degree of mychorrizal infection. These conclusions are supported by recent work in a longleaf pine forest in the USA [Guo et al., 2008a] and on 23 temperate tree species in China [Guo et al., 2008b]. In these studies, both branch order and diameter were correlated with different anatomical traits (e.g,, cortex thickness, stele diameter, presence or absence of secondary xylem or cork cambium); however, the correlations were much stronger for branch order. In China, branch order explained many anatomical differences in all species $(\mathrm{p}<0.01)$, but the correlation between diameter and order varied greatly with species type; sometimes not varying for five orders ( 2 species), or varying only after the third order (13 species), or increasing steadily with order (8 species) [Guo et al., 2008b]. Their results demonstrate that branch order correlates strongly with root anatomical traits regardless of species, whereas diameter may or may not, depending on species.

The relationship of diameter size class to fine-root turnover time has varied in the literature. A strong relationship with diameter was found in minirhizotron studies of apple, peach, and grape [Anderson et al., 2003; Wells and Eissenstat, 2001; Wells et al., 2002] and in a ${ }^{13} \mathrm{C}$ Free Air Enrichment study in loblolly pine [Matamala et al., 2003]. In contrast, a ${ }^{14} \mathrm{C}$ study of mixed-species roots from a mixed deciduous forest found only a weak relationship with turnover time [Joslin et al., 2006]. Finally, a minirhizotron study by [Withington et al., 2006], found that turnover time (of 
first and second order roots) was significantly related to diameter in only 4 out of 11 species growing in monoculture plots. Variability in results can be explained if diameter sometimes relates to turnover time, and the presence and strength of a relationship is a function of species.

Predicted values for long-lived root mean age and turnover time tended to be longer for roots sampled by diameter size class than by branch order (Table 4). However, it is unclear whether this indicates a systematic difference between the two sampling methods, for several reasons. First, branch-order samples were species specific, and core samples were mixed species. Second, branchorder results had a high degree of variability among root segments (Figure 5) implying some root segments may have been adventitious (i.e., the entire root segment was young), while others were not. Third, it may be possible that live roots sampled by soil coring and sorted by diameter size class were more likely to include dead roots (which would have higher relative $\Delta^{14} \mathrm{C}$ ) than branchorder samples from a live root branch.

\section{Carbon and Isotope Mass Balance}

To test Radix predictions of root respiration and its isotopic signature, we used published data from Harvard Forest ([Gaudinski et al., 2000]). In 1996, the annual flux of $\mathrm{CO}_{2}$ at Harvard Forest was $840 \mathrm{~g} \mathrm{C} \mathrm{m}^{-2} \mathrm{y}^{-1}$ and the ${ }^{14} \mathrm{CO}_{2}$ signature of total and heterotrophic soil respiration was $129 \pm 9 \%$. Combining these data with predictions from Radix of (1) heterotrophic respiration of dead roots and (2) autotrophic root respiration, we performed an overall C and ${ }^{14} \mathrm{C}$ mass balance for 1996 (see SI Table 4 for parameters used and their sources). The predicted $\Delta^{14} \mathrm{C}$ value of total soil respiration was $131 \%$, well within the range predicted by Gaudinski et al. [2000]. However, a wide range of possible partitioning between the belowground $\mathrm{C}$ fluxes are consistent with the observed soil respiration, primarily because we were unable to characterize the magnitude and ${ }^{14} \mathrm{C}$ content of root 
exudation, sloughing, etc. Further development of Radix and similar models should focus on quantifying these other potentially large $\mathrm{C}$ fluxes between the plants and soil.

\section{Implications for Future Research}

Analysis of bomb- ${ }^{14} \mathrm{C}$ in fine-root tissues has been very helpful in establishing that a significant portion of the fine-root system has decadal-scale turnover times [Gaudinski et al., 2001; Trumbore et al., 2006] and in distinguishing between annual and decadal turnover times (Figure 6). However, the technique is limited in its ability to quantify precisely (i.e., to within one or two years) mean turnover times for root populations sorted by the methods reported here (e.g., depth and diameter size class or order). With this technique the standard error (SE) in measured $\Delta{ }^{14} \mathrm{C}$ values for a given population is large (generally $\geq 6-20 \%$ ) relative to the $\mathrm{SE}$ of $<4-10 \%$ required to determine a one to two year difference in $\tau_{L 23}$. Sorting roots based on site-specific knowledge of how root physical characteristics (e.g., stiffness, color) relate to root age would be painstaking but might decrease variability in sample means. Other isotopic approaches such as time-series sampling at sites with continuous ${ }^{13} \mathrm{C}$ labeling, such as free air isotopic carbon enrichment (FACE) sites, may allow increased resolution of fine-root turnover times.

The Radix configuration of two live-root pools, each with a positively skewed lognormal distribution, is not the only way to model mortality behavior in fine roots [Luo, 2003]. However, Radix predictions provide a good fit to available data, and it is the first model that is consistent with both minirhizotron and ${ }^{14} \mathrm{C}$ data. Future modeling efforts should examine: (1) the impacts of alternate or multiple mortality distributions [Guo et al., 2008a; Luo, 2003]; (2) the inclusion of more pools, potentially based on branch order, and including roots $>2 \mathrm{~mm}$ in diameter; and (3) impacts of stored C use on isotopic signatures under conditions of high stress [Vargas et al., 2009]. Future field efforts should focus on improving our ability to isolate roots cycling at different rates and to 
better quantify root respiration and exudation. Validation of any new representations with

observational constraints based on stocks and fluxes of $\mathrm{C},{ }^{13} \mathrm{C}$, and ${ }^{14} \mathrm{C}$ [Trumbore et al., 2006] will be very important.

\section{Conclusions}

Research quantifying $\mathrm{C}$ fluxes into soil from root mortality has focused on the most dynamic portion of the population. Typically, this has been done using an arbitrary diameter-size-class cutoff similar to the $<2 \mathrm{~mm}$ cutoff used in this study. We show, however, that of the $<2 \mathrm{~mm}$ size-class fraction, $80 \%$ of the biomass has decadal-scale cycling rates and only $20 \%$ cycles on annual time scales. This flux partitioning is reflected in the mean age $(A)$ of the entire $<2 \mathrm{~mm}$ live-root biomass being $\sim 9 \mathrm{y}$, while the mean age of roots leaving the system via mortality $(\tau)$ is $\sim 3 \mathrm{y}$. To make these estimates our model (Radix) required: (1) minirhizotron and ${ }^{14} \mathrm{C}$ data to estimate the short- and long-lived root pool turnover times (respectively); (2) information on their likely turnover-time distribution; and (3) site-specific measured total fine-root biomass. Information on the cycling rates of just one pool from minirhizotrons or ${ }^{14} \mathrm{C}$ would have been inadequate to determine the mean behavior; both are required.

Using the short- and long-lived root pools characterized here is an improvement over singlepool approaches, yet it is still likely to be an oversimplification. Our estimates of BCA and BNPP* (where BNPP* is the annual new biomass increment) are 20 to $80 \%$ smaller, depending on the forest, than previous estimates for the same sites. This result is not surprising, given that we are newly accounting for a large portion of fine-root biomass with decadal turnover times. However, just how complicated modeling needs to be to make accurate estimates of $\mathrm{C}$ fluxes to soil from root mortality should continue to be investigated. 
Finally, we find a correlation between $\Delta{ }^{14} \mathrm{C}$ values and both diameter size class and position on the root branch. However, our data suggest that the efficacy of diameter size class sorting to isolate cycling rates may vary as a function of dominant species type — whereas branch order, probably because it is based on root physiological structure, is more likely to separate roots into groups with similar cycling rates regardless of species type. 


\section{Acknowledgments}

Hooshang Majdi passed away before this manuscript was completed. He will be missed by these authors as a talented colleague and a friend. We would like to thank Jan-Erik Nylund (Swedish University of Agricultural Sciences) for reviewing this manuscript on Hooshang's behalf. We also thank Kathleen Savage, Heather Cooley, Anders Walin, and Bertil Andersson for assistance in the

field; Marc Los Huertos, Jessica Westbrook, Deborah Williard, John Southon, and Rachel Porras for help in the lab. Julia Gaudinski thanks Weixin Cheng for mentorship and laboratory support throughout this research. This work was supported by the Director, Office of Science, Office of Biological and Environmental Research, Climate Change Research Division, of the U.S. Department of Energy under Contract No. DE-AC02-05CH11231. 


\section{Figure Captions}

Figure 1. Branch order sampling. A. Large Acer rubrum root used for sampling. B. Microscopic view of red maple root showing orders 1-3 including mycorrhizal short roots. The pattern for assigning branch order continues for larger orders (i.e. when two $3^{\text {rd }}$ order roots come together the root becomes $4^{\text {th }}$ order).

Figure 2. $\Delta{ }^{14} \mathrm{C}$ history of the Northern Hemisphere and the local history at our three study sites. A.1950-2004. B. 1995-2004. Northern Hemisphere data (solid line) for 1950-1976 are from Levin and Hessheimer 2000, and those for 1977-2003 are from Levin and Kromer 2004. Local data are from tree ring cellulose (open symbols) or point air samples (closed symbols). Harvard Forest data are shown using triangles, Blodgett Forest with circles and Knottåsen with squares. Air data from Harvard Forest 1996-1999 is from [Gaudinski, 2001]. Elevated levels of ${ }^{14} \mathrm{C}$ in atmospheric $\mathrm{CO}_{2}$ were the result of thermonuclear weapons testing in the early 1960's. Subsequent decreases were due to atmospheric $\mathrm{CO}_{2}$ exchange with the ocean and terrestrial biospheres and dilution by ${ }^{14} \mathrm{C}$-free fossil fuel emissions.

Figure 3. The structure of the Radix model [Riley et al., 2009]. Radix represents C flows through fine roots with the following pools: storage $(S)$, live roots with fast turnover $\left(L_{1}\right)$, live roots with slower turnover (divided into nonstructural $\left(L_{2}\right)$ and structural $\left(L_{3}\right)$ components), dead roots with faster turnover $\left(D_{1}\right)$, and dead roots with slower turnover $\left(D_{2}\right)$. In this study, we did not use the decomposition portion of the model. A fraction $\left(f_{s}\right)$ of recently fixed photosynthate is stored in the storage pool while the remainder $\left(1-f_{s}\right)$ is used immediately by roots. The transfer of $\mathrm{C}$ out of the storage pool is controlled by its turnover time $\left(\tau_{s}\right)$ and size. Carbon from recent photosynthate and storage is directed to the live pools using the parameters $f_{l}$ and $f_{2}$ (both set to 0.5 [Riley et al., 
2009]). $L_{l}$ can lose carbon via respiration $\left(R_{I}\right)$ and mortality $\left(\tau_{L l}\right)$. Because these roots are short lived, we assume there is no significant isotopic difference between nonstructural, structural, and respired C. Pools $L_{2}$ and $L_{3}$ collectively comprise living long-lived fine roots. $L_{2}$ represents total nonstructural carbohydrates (TNC), while $L_{3}$ represents the structural (cellulose) portion of longlived fine roots. $L_{2}$ receives stored and new photosynthate and loses $\mathrm{C}$ via respiration $\left(R_{2}\right)$, transfer of carbon to $L_{3}$ (characterized by the turnover time $\left.\tau_{t s}\right)$, and mortality $\left(\tau_{L 23}\right)$. The value of $\tau_{t s}(0.5 \mathrm{y})$ yields seasonally reasonable values for the mass of $L_{2}$ [Riley et al. 2009]. $L_{3}$ receives $\mathrm{C}$ from $L_{2}$ and loses carbon via root mortality $\left(\tau_{L 23}\right)$. The turnover times for $L_{2}$ and $L_{3}$ are equivalent because when a root dies, both TNC and structural pools turnover simultaneously.

Figure 4. $\Delta{ }^{14} \mathrm{C}$ values by site and soil horizon for roots measured by diameter size class. Legend in the upper left of each series of figures indicates the site-specific unit from which the samples originated (see text in Table 1).

Figure 5. $\Delta{ }^{14} \mathrm{C}$ values by branch order for each of our three sites. A. Harvard Forest (samples are Acer rubrum). B. Blodgett Forest (samples are Pinus ponderosa). C. Knottåsen (samples are Picea abies). Each individual root segment is plotted with its own symbol (except at Harvard Forest where each symbol represents a composite from 3 root segments along the same transect).

Figure 6. Sensitivity of $\mathrm{L}_{1}+\mathrm{L}_{2}+\mathrm{L}_{3} \Delta^{14} \mathrm{C}$ values at Harvard Forest to $\tau_{L 23}$. In each run, $\tau_{\mathrm{L} 1}$ equals 0.8 y. 


\section{Tables}

\section{Table 1. Details of soil coring and branch-order sampling at Harvard Forest, Blodgett Forest, and Knottåsen.}

\begin{tabular}{|c|c|c|c|c|c|}
\hline Soil Coring & Sample Date & $\begin{array}{l}\text { Site Sample } \\
\text { Unit }\end{array}$ & $\begin{array}{l}\text { Cores per } \\
\text { Unit } \\
\text { (per Site) }\end{array}$ & $\begin{array}{l}\text { Cores } \\
\text { Analyzed } \\
\text { For }{ }^{14} \mathrm{C}\end{array}$ & Depths Sampled (cm) \\
\hline $\begin{array}{l}\text { Harvard } \\
\text { Forest }\end{array}$ & June 1-4, 2001 & 4 Transects $^{\mathrm{b}}$ & $5(20)$ & $13^{\mathrm{c}}$ & O horizon $^{\mathrm{d}}, 0-5,5-25$ \\
\hline $\begin{array}{l}\text { Blodgett } \\
\text { Forest }\end{array}$ & June 5-7, 2002 & 3 Units $^{\mathrm{e}}$ & $8(24)$ & $15^{\mathrm{f}}$ & $\begin{array}{l}\text { O horizon }^{\mathrm{d}}, 0-10,10-30,30- \\
60\end{array}$ \\
\hline Knottåsen & Sept. 1-2, 2002 & 3 Plots $^{g}$ & $3(9)$ & 9 & O horizon $^{\mathrm{d}}, 0-10,10-30$ \\
\hline $\begin{array}{l}\text { Branch } \\
\text { Order }\end{array}$ & Species & Sample Date & $\begin{array}{c}\text { Sampling } \\
\text { Method }\end{array}$ & $\begin{array}{c}\text { Samples } \\
\text { Collected } \\
\end{array}$ & Segments Analyzed for ${ }^{14} C^{h}$ \\
\hline $\begin{array}{l}\text { Harvard } \\
\text { Forest }\end{array}$ & Acer rubrum & "June 1-4, 2001 & In situ & 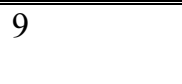 & 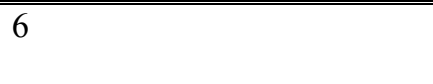 \\
\hline $\begin{array}{l}\text { Blodgett } \\
\text { Forest }\end{array}$ & $\begin{array}{l}\text { Pinus } \\
\text { ponderosa }\end{array}$ & June 5-7, 2002 & $\begin{array}{l}\text { In } \\
\text { situ/Block }\end{array}$ & 6 & 5 \\
\hline Knottåsen & Picea abies & $\begin{array}{l}\text { Aug. 12, } 2002 \\
\text { Sept 2, 2001 }\end{array}$ & $\begin{array}{l}\text { In } \\
\text { situ/Block }\end{array}$ & 7 & 5 \\
\hline
\end{tabular}

\footnotetext{
${ }^{a}$ All cores were extracted with stainless steel corers. The following diameter corers were used: At Harvard Forest, 5.35 cm; Blodgett Forest, $5.35 \mathrm{~cm}$ except 30-60 cm depth interval, $4.8 \mathrm{~cm}$; Knottåsen, $\mathrm{O}$ horizon, $7.2 \mathrm{~cm}$,mineral horizons 5 $\mathrm{cm}$.

${ }^{\mathrm{b}}$ At Harvard Forest, four $400 \mathrm{M}$ transects radiated from the EMS tower at $226^{\circ}, 248^{\circ}, 309^{\circ}$ and $320^{\circ}$ magnetic. Cores were taken at $80 \mathrm{~m}$ intervals along each transect.

${ }^{\mathrm{c}}$ For each transect the best 3 or 4 soil cores (those with the least amount of rock interference) were chosen for sorting and analysis.

${ }^{\mathrm{d}}$ The organic horizon (O horizon) depth varied, with samples taken to its base, which became the top $(0 \mathrm{~cm})$ of the mineral soil horizons.

${ }^{\mathrm{e}}$ At Blodgett Forest, cores were taken at $35 \mathrm{M}$ intervals along two $140 \mathrm{M}$ transects established at each of 3 different management units (units 630, 450 and 120/140).

${ }^{\mathrm{f}}$ For each of the two transects per unit, the best 2 or 3 soil cores (usually based on proximity to ponderosa pine) were chosen for sorting and analysis.

${ }^{\mathrm{g}}$ At Knottåsen cores were taken in three plots named P4, P5 and P6.

${ }^{\mathrm{h}} \mathrm{We}$ analyzed the root segments that had the most mass in all branch orders.
} 
Table 2. Source and estimates of $\tau_{L 1}$ and $R_{1}$ values used in Radix.

\begin{tabular}{|c|c|c|c|c|c|}
\hline $\begin{array}{l}\text { Site } \\
\text { Depth }\end{array}$ & $\begin{array}{l}\tau_{L 1} \\
\text { (days) }^{\mathrm{a}}\end{array}$ & $\begin{array}{l}\text { Mean Soil T } \\
\left({ }^{\circ} \mathrm{C}\right)^{b}\end{array}$ & Equation for $R^{c}$ & $\begin{array}{l}R \text { values } \\
\left(\mu \mathrm{gC} \mathrm{g}^{-1} \mathrm{~s}^{-1}\right)^{\mathrm{d}}\end{array}$ & $\begin{array}{l}\text { Seasonal } \\
\text { periods } \\
\text { (Julian Days) }^{\mathrm{e}} \\
\end{array}$ \\
\hline $\begin{array}{l}\text { Harvard Forest } \\
\text { O Horizon } \\
0-5 \mathrm{~cm} \\
5-25 \mathrm{~cm}\end{array}$ & $\begin{array}{l}314 \\
314 \\
314 \\
\end{array}$ & $\begin{array}{l}9.2,16.8,9.3,1.6(4.5) \\
8.9,13.7,9.8,1.4(8.5) \\
8.0,12.3,10.6,3.2(14 / 36)\end{array}$ & $\mathrm{R}=0.0041 \mathrm{e}^{0.1301 T s}$ & $\begin{array}{l}0.004,0.010,0.004,0.001 \\
0.004,0.007,0.004,0.001 \\
0.003,0.006,0.005,0.002\end{array}$ & $\begin{array}{l}86-174,175-272 \\
273-315,316-85\end{array}$ \\
\hline $\begin{array}{l}\text { Blodgett Forest } \\
\text { O Horizon } \\
0-10 \mathrm{~cm} \\
10-30 \mathrm{~cm} \\
30-60 \mathrm{~cm}\end{array}$ & $\begin{array}{l}390 \\
390 \\
390 \\
650\end{array}$ & $\begin{array}{l}7.4,13.6,6.8,2.9 \\
6.8,12.6,7.5,3.4 \\
\mathrm{f} \\
\mathrm{f}\end{array}$ & $\mathrm{R}=0.0447 \mathrm{Q}_{10}((\mathrm{Ts}-18) / 10)$ & $\begin{array}{l}0.016,0.029,0.015,0.010 \\
0.015,0.026,0.016,0.011 \\
0.015,0.026,0.016,0.011^{\mathrm{f}} \\
0.015,0.026,0.016,0.011^{\mathrm{f}}\end{array}$ & $\begin{array}{l}124-150,151-284 \\
285-346,347-123\end{array}$ \\
\hline $\begin{array}{l}\text { Knottåsen } \\
\text { O Horizon } \\
0-10 \mathrm{~cm} \\
10-30 \mathrm{~cm}\end{array}$ & $\begin{array}{l}391 \\
365 \\
391\end{array}$ & $\begin{array}{l}7.0,11.9,5.7,0.7(3) \\
7.0,11.9,5.7,0.7(3) \\
6.6,11.7,6.9,1.9(15)\end{array}$ & $\mathrm{R}=0.18 \mathrm{e}^{0.16 \mathrm{Ts}}$ & $\begin{array}{l}0.007,0.014,0.005,0.002 \\
0.007,0.014,0.005,0.002 \\
0.006,0.014,0.007,0.003\end{array}$ & $\begin{array}{l}117-179,180-264 \\
265-304,305-116\end{array}$ \\
\hline
\end{tabular}

${ }^{a}$ Based on median lifespan data for the $\mathrm{L}_{1}$ pool. Sources; (1) for Harvard Forest, Tierney and Fahey [2001]; from Hubbard Brook Experimental Forest, NH, USA; dominant tree species are sugar maple (Acer saccharum Marsh), beech (Fagus grandifola Ehrh.), and yellow birch (Betula alleghaniensis Brit.); (2) for Blodgett Forest, Alexander Gershenson (unpublished data); (3) for Knottåsen, Hooshang Majdi (pers comm), Kleja et al. [2008]

${ }^{\mathrm{b}}$ Mean soil temperature values for the four seasonal periods listed respectively in the last column of this table. The last value in parentheses is the soil depth in $\mathrm{cm}$ at which the temperature was recorded. These values are $\mathrm{T}_{\mathrm{s}}$ in the equation for $\mathrm{R}_{\mathrm{r}}$ or are used in the $\mathrm{Q}_{10}$ calculation. Sources: (1) for Harvard Forest, Davidson and Savage (unpublished data); (2) for Blodgett Forest, [Bird and Torn, 2006]]; (3) for Knottåsen, Hooshang Majdi (pers comm.). ${ }^{c}$ Equation used to calculate root respiration where $R_{r}=$ root respiration and $T_{s}$ equals soil temperature. Sources: (1) for Harvard forest, equation comes from fit to unpublished data by Davidson and Savage for mixed species roots $<2$ $\mathrm{mm}$ in diameter at ambient $\mathrm{CO}_{2} ;(2)$ for Blodgett Forest, we used a root respiration rate $\left(0.0447 \mathrm{ugC} \mathrm{g}^{-1} \mathrm{~s}^{-1}\right)$ and $\mathrm{Q}_{10}$ (2.7) from Burton et al. [2002] and the average of four ectomychorrizal gymnosperms measured at $18{ }^{\circ} \mathrm{C}$ ) to calculate average respiration rates for the four seasonal periods;(3) for Knottåsen, the equation comes from Widen and Majdi [2001], for $<5.0 \mathrm{~mm}$ diameter roots of Scots pine (Pinus sylvestris L.) and Norway spruce (Picea abies (L.) Karst).

${ }^{\mathrm{d}}$ Root respiration values from the four seasonal periods listed respectively in the last column of this table. See text for details on the calculation.

e The four seasonal periods listed here, represent the Julian Day range to which the respective four values for mean soil T and R correspond (column 4 and 6 respectively) and are based on temperature changes in the soil profile.

${ }^{\mathrm{f}}$ There are no temperature data below $10 \mathrm{~cm}$ so we use the data for the $0-10 \mathrm{~cm}$ horizon. 
Table 3. Statistical significance for linear regressions of root $\Delta^{14} \mathrm{C}$ on diameter (by depth) and branch order for fine roots.

\begin{tabular}{|c|c|c|c|c|c|}
\hline $\begin{array}{l}\text { Regression of }{ }^{14} \mathrm{C} \text { Core } \\
\text { Data by diameter size } \\
\text { class }^{1}\end{array}$ & Horizon & $\mathbf{R}^{2}$ & $\mathbf{P}$ & Slope & b \\
\hline \multirow[t]{4}{*}{ Harvard Forest } & $\mathrm{O}$ & 0.126 & 0.125 & 8 & 124 \\
\hline & Min 1 & 0.356 & 0.007 & 42 & 125 \\
\hline & Min 2 & 0.065 & 0.277 & -15 & 168 \\
\hline & All Depths & 0.039 & 0.134 & 12 & 139 \\
\hline \multirow[t]{5}{*}{ Blodgett Forest } & $\mathrm{O}$ & 0.479 & 0.013 & 79 & 58 \\
\hline & Min 1 & 0.290 & 0.047 & 36 & 112 \\
\hline & $\operatorname{Min} 2$ & 0.133 & 0.165 & 25 & 129 \\
\hline & Min 3 & 0.083 & 0.298 & 38 & 124 \\
\hline & All Depths & 0.173 & 0.001 & 41 & 110 \\
\hline \multirow[t]{4}{*}{ Knottåsen } & $\mathrm{O}$ & 0.389 & 0.013 & 25 & 111 \\
\hline & Min 1 & 0.000 & 0.98 & 0 & 140 \\
\hline & $\operatorname{Min} 2$ & 0.001 & 0.900 & -2 & 127 \\
\hline & All Depths & 0.028 & 0.281 & 8 & 126 \\
\hline $\begin{array}{l}\text { ANOVA Analysis of } \\
\text { Factors: P Values }\end{array}$ & Diameter & Depth & \multicolumn{3}{|c|}{$\begin{array}{l}\text { Diameter } \\
\text { and Depth }\end{array}$} \\
\hline Harvard Forest & 0.295 & 0.003 & 0.021 & & \\
\hline Blodgett Forest & 0.035 & 0.869 & 0.726 & & \\
\hline Knottåsen & 0.649 & 0.322 & 0.634 & & \\
\hline $\begin{array}{l}\text { Regression of }{ }^{14} \mathrm{C} \\
\text { Branch Order Data }\end{array}$ & Root \# & $\mathbf{R}^{2}$ & $\mathbf{P}$ & Slope & $\mathbf{b}$ \\
\hline \multirow[t]{3}{*}{ Harvard Forest } & $1^{4}$ & 0.626 & 0.111 & 11 & 91 \\
\hline & $2^{4}$ & 0.474 & 0.198 & 5 & 93 \\
\hline & All Roots & 0.094 & 0.135 & 14 & 76 \\
\hline \multirow[t]{6}{*}{ Blodgett Forest } & 1 & 0.823 & 0.013 & 12 & 58 \\
\hline & 2 & 0.684 & 0.042 & 13 & 36 \\
\hline & 3 & 0.930 & 0.008 & 48 & 29 \\
\hline & 4 & 0.997 & 0.033 & 41 & 67 \\
\hline & 5 & 0.360 & 0.016 & 4 & 61 \\
\hline & All Roots & 0.421 & 0.042 & 8 & 92 \\
\hline \multirow[t]{6}{*}{ Knottåsen } & 1 & 0.763 & 0.127 & 7 & 81 \\
\hline & 2 & 0.925 & 0.038 & 9 & 45 \\
\hline & 3 & 0.936 & 0.032 & 12 & 56 \\
\hline & 4 & 0.708 & 0.074 & 6 & 108 \\
\hline & 5 & 0.778 & 0.048 & 6 & 87 \\
\hline & All Roots & 0.285 & 0.010 & 7 & 78 \\
\hline
\end{tabular}

\footnotetext{
${ }^{1}$ Regressions use diameter size classes as represented by numeric values $0.3,0.5,0.8,1.1$ and 2 to relate to size classes $<0.3 \mathrm{~mm}, 0.3-<0.5 \mathrm{~mm}, 0.5-<0.8 \mathrm{~mm}, 0.8-<1.1$ and $1.1-2 \mathrm{~mm}$ respectively.

${ }^{2}$ Regressions use numbers 1-7 to represent orders 1-7. For Blodgett Forest and Knottåsen where orders 1 and 2 are combined there is no order 1 represented and they are lumped into the second order.

${ }^{3}$ For all orders measured.

${ }^{4}$ Represents composits of 3 separate root segments, composited by order, from samples along either transect 226 or 248 .
} 
Table 4. $\tau_{L 23}, A_{L 23}, \tau_{L 123}, A_{L 123}$ by site, depth, and size class.

\begin{tabular}{|c|c|c|c|c|c|c|c|c|c|c|c|c|c|c|c|c|}
\hline \multirow{2}{*}{$\begin{array}{l}\text { Diameter }(\mathrm{mm}) \\
\text { Harvard Forest }^{1}\end{array}$} & \multicolumn{4}{|c|}{ O horizon } & \multicolumn{4}{|c|}{ Mineral 1} & \multicolumn{4}{|c|}{ Mineral 2} & \multicolumn{4}{|c|}{ Mineral 3} \\
\hline & $\tau_{L 23}$ & $A_{L 23}$ & $\tau_{L 123}$ & $A_{L 123}$ & $\tau_{L 23}$ & $A_{L 23}$ & $\tau_{L 123}$ & $A_{L 123}$ & $\tau_{L 23}$ & $A_{L 23}$ & $\tau_{L 123}$ & $A_{L 123}$ & $\tau_{L 23}$ & $A_{L 23}$ & $\tau_{L 123}$ & $A_{L 123}$ \\
\hline$<0.3$ & 5 & 8 & 3 & 6 & 10 & 14 & 4 & 11 & 10 & 14 & 4 & 11 & & & & \\
\hline $0.3-<0.5$ & 6 & 9 & 3 & 6 & 6 & 9 & 3 & 7 & 14 & 21 & 4 & 16 & & & & \\
\hline $0.5-<0.8$ & 7 & 10 & 3 & 7 & 8 & 11 & 3 & 8 & 8 & 12 & 4 & 9 & & & & \\
\hline $0.8-<1.1$ & 6 & 9 & 3 & 7 & 13 & 17 & 4 & 14 & 6 & 9 & 3 & 7 & & & & \\
\hline $1.1-2$ & 7 & 10 & 4 & 7 & $\geq 15$ & $\geq 22$ & 5 & 18 & 8 & 12 & 4 & 9 & & & & \\
\hline \multicolumn{17}{|l|}{ Blodgett Forest $^{2}$} \\
\hline$<0.3$ & 11 & 16 & 4 & 12 & 9 & 13 & 4 & 10 & 7 & 10 & 3 & 7 & 8 & 12 & 5 & 9 \\
\hline $0.3-<0.5$ & 2 & 3 & 2 & 2 & 8 & 11 & 3 & 8 & 10 & 14 & 4 & 11 & 6 & 9 & 4 & 6 \\
\hline $0.5-<0.8$ & 8 & 11 & 3 & 8 & 7 & 10 & 3 & 7 & 12 & 18 & 4 & 13 & 11 & 15 & 5 & 11 \\
\hline $0.8-<1.1$ & 6 & 9 & 3 & 6 & 8 & 12 & 4 & 9 & 12 & 18 & 4 & 13 & $\geq 15$ & $\geq 22$ & 6 & 18 \\
\hline $1.1-2$ & $\geq 15$ & $\geq 22$ & 5 & 18 & $\geq 15$ & $\geq 22$ & 5 & 18 & 15 & 22 & 5 & 18 & $\geq 15$ & $\geq 22$ & 6 & 17 \\
\hline \multicolumn{17}{|l|}{ Knottåsen $^{3}$} \\
\hline$<0.3$ & 6 & 9 & 3 & 6 & 8 & 12 & 3 & 9 & 4 & 6 & 2 & 4 & & & & \\
\hline $0.3-<0.5$ & 5 & 7 & 3 & 5 & 8 & 12 & 3 & 9 & 5 & 8 & 3 & 5 & & & & \\
\hline $0.5-<0.8$ & 7 & 10 & 3 & 7 & 7 & 10 & 3 & 7 & 8 & 11 & 3 & 8 & & & & \\
\hline $0.8-<1.1$ & 8 & 11 & 3 & 8 & 9 & 13 & 3 & 9 & 8 & 12 & 3 & 9 & & & & \\
\hline $1.1-2$ & 11 & 16 & 4 & 12 & 8 & 12 & 3 & 9 & 5 & 7 & 3 & 5 & & & & \\
\hline \multicolumn{17}{|l|}{ Branch Order ${ }^{4}$} \\
\hline Harvard Forest ${ }^{1}$ & $\tau_{23}$ & $A_{23}$ & $\tau_{123}$ & $A_{123}$ & & & & & & & & & & & & \\
\hline 1 & 2 & 3 & 2 & 2 & & & & & & & & & & & & \\
\hline 2 & 4 & 6 & 2 & 4 & & & & & & & & & & & & \\
\hline 3 & 5 & 8 & 3 & 6 & & & & & & & & & & & & \\
\hline 4 & 6 & 9 & 3 & 7 & & & & & & & & & & & & \\
\hline 5 & 5 & 8 & 3 & 6 & & & & & & & & & & & & \\
\hline \multicolumn{17}{|l|}{ Blodgett Forest $^{2}$} \\
\hline $1+2$ & 3 & 4 & 2 & 3 & & & & & & & & & & & & \\
\hline 3 & 5 & 8 & 3 & 6 & & & & & & & & & & & & \\
\hline 4 & 9 & 13 & 4 & 10 & & & & & & & & & & & & \\
\hline 5 & 11 & 16 & 4 & 12 & & & & & & & & & & & & \\
\hline \multicolumn{17}{|l|}{ Knottåsen $^{3}$} \\
\hline $1+2$ & 2 & 3 & 2 & 2 & & & & & & & & & & & & \\
\hline 3 & 4 & 6 & 2 & 4 & & & & & & & & & & & & \\
\hline 4 & 5 & 7 & 3 & 5 & & & & & & & & & & & & \\
\hline 5 & 5 & 7 & 3 & 5 & & & & & & & & & & & & \\
\hline
\end{tabular}

${ }^{1}$ At Harvard Forest $\tau_{1}=0.86$ y. $A_{1}=1.2 \mathrm{y}$

${ }^{2}$ At Blodgett Forest $\tau_{1}=1.1 \mathrm{y}$ except in the mineral 3 horizon where $\tau_{l}=1.8 \mathrm{y} . \quad A_{l}=1.5$ or $2.6 \mathrm{y}$

${ }^{3}$ At Knottåsen $\tau_{1}=1 \mathrm{y}$ in the mineral 1 horizon and $1.1 \mathrm{y}$ in the $\mathrm{O}$ horizon and mineral 2 horizon. $\mathrm{A}_{1}=1.4$ or $1.6 \mathrm{y}$

${ }^{4}$ For orders 1-5 only (see text for explanation).

$\geq$ The value is at least as large as indicated and maybe larger. However, our model is not sensitive for values of $\tau_{L 23} \geq$ 15 or $A_{L 23} \geq 22 \mathrm{y}$. 
Table 5. BCA and BNPP*

\begin{tabular}{|c|c|c|c|c|c|c|c|c|c|}
\hline $\begin{array}{l}\text { Method } \\
\text { Site }\end{array}$ & $\begin{array}{l}B C A \\
g C m^{-2} y^{-1}\end{array}$ & $\begin{array}{l}\text { BNPP* } \\
\text { Short-Lived } \\
\text { Roots } \\
\text { gC } \mathrm{m}^{-2} \mathrm{y}^{-1}\end{array}$ & $\begin{array}{l}\text { BNPP* } \\
\text { Long-Lived } \\
\text { Roots } \\
\text { gC m }{ }^{-2} \mathrm{y}^{-1}\end{array}$ & 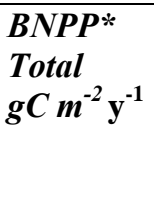 & $\begin{array}{l}\text { Live Fine } \\
\text { Root } \\
\text { Biomass } \\
\text { (Measured) }^{a} \\
\text { gC } \text { m }^{-2}\end{array}$ & $\begin{array}{l}\text { Live Fine } \\
\text { Root } \\
\text { Biomass }^{a} \\
\text { (Predicted) }_{\text {gC } \text { m }^{-2}}\end{array}$ & $\begin{array}{l}\text { Biomass } \\
\text { Short- } \\
\text { Lived } \\
\text { Roots } \\
\text { gC } \mathrm{m}^{-2} \mathrm{y}^{-1}\end{array}$ & $\begin{array}{l}\text { Published } \\
\text { Fine root } \\
\text { production } \\
(\text { BNPP*) }\end{array}$ & $\begin{array}{l}\text { Total } \\
N P P \\
g C m^{-2} y^{-1}\end{array}$ \\
\hline \multicolumn{9}{|l|}{ Diameter Size } & \\
\hline Harvard Forest & 152 & 51 & 21 & 72 & $264 \pm 18$ & 268 & 59 & $270^{\mathrm{b}}$ & $565^{\mathrm{c}}$ \\
\hline Blodgett Forest & 139 & 32 & 6 & 38 & $185 \pm 36$ & 199 & 31 & $169^{\mathrm{d}}$ & $400^{\mathrm{d}}$ \\
\hline Knottåsen & 205 & 59 & 20 & 79 & $274 \pm 30$ & 254 & 58 & $132^{\mathrm{e}}$ & $357^{\mathrm{e}}$ \\
\hline \multicolumn{10}{|l|}{ Branch Order } \\
\hline Harvard Forest & 171 & 59 & 34 & 93 & $264 \pm 18^{2}$ & 263 & 58 & $270^{\mathrm{b}}$ & $565^{\mathrm{c}}$ \\
\hline Blodgett Forest & 178 & 40 & 5 & 45 & $185 \pm 36^{2}$ & 185 & 37 & $169^{\mathrm{d}}$ & $400^{\mathrm{d}}$ \\
\hline Knottåsen & 244 & 37 & 67 & 104 & $274 \pm 30^{2}$ & 263 & 70 & $132^{\mathrm{e}}$ & $357^{\mathrm{e}}$ \\
\hline
\end{tabular}

a Total fine root biomass for the $\mathrm{L}_{1}+\mathrm{L}_{23}$ pools.

${ }^{\mathrm{b}}$ Estimate is from a similar 80-year-old mixed hardwood stand also at Harvard Forest and is based on the max-min sequential coring technique for roots $<0.3 \mathrm{~mm}$ [McClaugherty et al., 1982] and an assumption of $50 \% \mathrm{C}$ content for fine roots.

${ }^{\mathrm{c}}$ Estimate is based on $\mathrm{C}$ budget approach [Curtis et al., 2002].

${ }^{\mathrm{d}}$ Estimate is an average of three ponderosa pine forests in Oregon ranging in age from 56-89 y [Law et al., 2003], as appropriate site specific data from Blodgett Forest were not available. Fine root production estimate includes $<2 \mathrm{~mm}$ roots and roots $2-20 \mathrm{~mm}$ in diameter and is based on site specific root sampling and modeling using Biome-BGC [Law et al., 2003].

${ }^{\mathrm{e}}$ Estimate is from the same site and plots studied here. NPP is based on modeling using CoupModel [Kleja et al., 2008]. Fine root production is based on estimates of fine $(<1 \mathrm{~mm})$ root biomass from cores and minirhizotron-derived estimates of fine root elongation [Kleja et al., 2008]. 


\section{References}

Anderson, L. J., L. H. Comas, A. N. Lakso, and D. M. Eissenstat (2003), Multiple risk factors in root survivorship: a 4-year study in Concord grape, New Phytol, 158(3), 489-501.

Barbour, M. M., J. S. Roden, G. D. Farquhar, and J. R. Ehleringer (2004), Expressing leaf water and cellulose oxygen isotope ratios as enrichment above source water reveals evidence of a Peclet effect, Oecologia, 138(3), 426-435.

Bird, J. A., and M. S. Torn (2006), Fine roots vs. Needles: A comparison of C-13 and N-15 dynamics in a ponderosa pine forest soil, Biogeochemistry, 79(3), 361-382.

Burton, A. J., K. S. Pregitzer, R. W. Ruess, R. L. Hendrik, and M. F. Allen (2002), Root respiration in North American forests: effects of nitrogen concentration and temperature across biomes, Oecologia, 131(4), 559-568.

Carbone, M. S., C. I. Czimczik, K. E. McDuffee, and S. E. Trumbore (2007), Allocation and residence time of photosyntheitc products in a boreal forest using a low-level 14C pulse-chase labeling technique, Glob Change Biol, 13, 466-477.

Clark, D. A., S. Brown, D. W. Kicklighter, J. Q. Chambers, J. R. Thomlinson, and J. Ni (2001), Measuring net primary production in forests: Concepts and field methods, Ecological Applications, 11(2), 356-370.

Curtis, P. S., P. J. Hanson, P. Bolstad, C. Barford, J. C. Randolph, H. P. Schmid, and K. B. Wilson (2002), Biometric and eddy-covariance based estimates of annual carbon storage in five eastern North American deciduous forests, Agricultural And Forest Meteorology, 113(1-4), 3-19.

Czimczik, C. I., S. E. Trumbore, M. S. Carbone, and G. C. Winston (2006), Changing sources of soil respiration with time since fire in a boreal forest, Glob Change Biol, 12(6), 957-971.

Fahey, T. J., G. L. Tierney, R. D. Fitzhugh, G. F. Wilson, and T. G. Siccama (2005), Soil respiration and soil carbon balance in a northern hardwood forest ecosystem, Canadian Journal Of Forest Research-Revue Canadienne De Recherche Forestiere, 35(2), 244-253.

Farquhar, G. D., B. K. Henry, and J. M. Styles (1997), A rapid on-line technique for determination of oxygen isotope composition of nitrogen-containing organic matter and water, Rapid Communications In Mass Spectrometry, 11(14), 1554-1560.

Fitter, A. H. (Ed.) (2002), Characteristics and functions of root systems, 15-32 pp., Dekker, New York.

Gaudinski, J. B. (2001), Belowground carbon cycling in three temperate forests of the eastern United States, Doctoral thesis, 306 pp, Doctoral Dissertation: University of California, Irvine, Irvine.

Gaudinski, J. B., S. E. Trumbore, E. A. Davidson, and S. Zheng (2000), Soil carbon cycling in a temperate forest: radiocarbon-based estimates of residence times, sequestration rates and partitioning of fluxes, Biogeochemistry, 51, 33-69.

Gaudinski, J. B., S. E. Trumbore, E. A. Davidson, A. C. Cook, D. Markewitz, and D. D. Richter (2001), The age of fine-root carbon in three forests of the eastern United States measured by radiocarbon, Oecologia, 129(3), 420-429.

Gaudinski, J. B., T. E. Dawson, S. Quideau, E. A. G. Schuur, J. S. Roden, S. E. Trumbore, D. R. Sandquist, S. W. Oh, and R. E. Wasylishen (2005), Comparative analysis of cellulose preparation techniques for use with C-13, C-14, and O-18 isotopic measurements, Analytical Chemistry, 77(22), $7212-7224$.

Gaudinski, J. B., M. S. Torn, W. J. Riley, C. Swanston, S. E. Trumbore, J. D. Joslin, H. Majdi, T. E. Dawson, and P. J. Hanson (2009), Use of stored carbon reserves in growth of temperate tree roots 
and leaf buds: analyses using radiocarbon measurements and modeling, Glob Change Biol, 15(4), 992-1014.

Gill, R. A., and R. B. Jackson (2000), Global patterns of root turnover for terrestrial ecosystems, New Phytol, 147(1), 13-31.

Guo, D. L., R. J. Mitchell, and J. J. Hendricks (2004), Fine root branch orders respond differentially to carbon source-sink manipulations in a longleaf pine forest, Oecologia, 140(3), 450-457.

Guo, D. L., R. J. Mitchell, J. M. Withington, P. P. Fan, and J. J. Hendricks (2008a), Endogenous and exogenous controls of root life span, mortality and nitrogen flux in a longleaf pine forest: root branch order predominates, Journal Of Ecology, 96(4), 737-745.

Guo, D. L., M. X. Xia, X. Wei, W. J. Chang, Y. Liu, and Z. Q. Wang (2008b), Anatomical traits associated with absorption and mycorrhizal colonization are linked to root branch order in twentythree Chinese temperate tree species, New Phytol, 180(3), 673-683.

Guo, D. L., H. Li, R. J. Mitchell, W. X. Han, J. J. Hendricks, T. J. Fahey, and R. L. Hendrick (2008c), Fine root heterogeneity by branch order: exploring the discrepancy in root turnover estimates between minirhizotron and carbon isotopic methods, New Phytol, 177(2), 443-456. Hanson, P. J., T. E. Nelson, T. J. Tschaplinski, S. D. Wullschleger, and J. D. Joslin (2003), Estimating the net primary and net ecosystem production of a southern upland quercus forest from an 8-year biometric record., in Changing Precipitation Regimes And Terrestrial Ecosystems: North American Perspective. Pg., edited by P. J. Hanson and S. D. Wullschlegger, pp. 378-395, Springer, New York.

Hendrick, R. L., and K. S. Pregitzer (1992), The Demography of Fine Roots in a Northern Hardwood Forest, Ecology, 73(3), 1094-1104.

Hogberg, P., and D. J. Read (2006), Towards a more plant physiological perspective on soil ecology, Trends In Ecology \& Evolution, 21(10), 548-554.

Hogberg, P., A. Nordgren, and G. I. Agren (2002), Carbon allocation between tree root growth and root respiration in boreal pine forest, Oecologia, 132(4), 579-581.

Hogberg, P., A. Nordgren, N. Buchmann, A. F. S. Taylor, A. Ekblad, M. N. Hogberg, G. Nyberg, M. Ottosson-Lofvenius, and D. J. Read (2001), Large-scale forest girdling shows that current photosynthesis drives soil respiration, Nature, 411(6839), 789-792.

Jackson, R. B., H. A. Mooney, and E.-D. Schulze (1997), A global budget for fine root biomass, surface area, and nutrient contents, Proc Nat Acad Sci Usa, 94(14), 7362-7366.

Joslin, J. D., J. B. Gaudinski, M. S. Torn, W. J. Riley, and P. J. Hanson (2006), Fine-root turnover patterns and their relationship to root diameter and soil depth in a 14-C labeled hardwood forest, New Phytol, 172, 523-535.

Keel, S. G., R. T. W. Siegwolf, and C. Korner (2006), Canopy CO2 enrichment permits tracing the fate of recently assimilated carbon in a mature deciduous forest, New Phytol, 172(2), 319-329.

Kleja, D. B., et al. (2008), Pools and fluxes of carbon in three Norway spruce ecosystems along a climatic gradient in Sweden, Biogeochemistry, 89(1), 7-25.

Law, B. E., O. J. Sun, J. Campbell, S. Van Tuyl, and P. E. Thornton (2003), Changes in carbon storage and fluxes in a chronosequence of ponderosa pine, Glob Change Biol, 9(4), 510-524. Levin, I., and V. Hesshaimer (2000), Radiocarbon - A unique tracer of global carbon cycle dynamics, Radiocarbon, 42(1), 69-80.

Levin, I., and B. Kromer (2004), The tropospheric (CO2)-C-14 level in mid-latitudes of the Northern Hemisphere (1959-2003), Radiocarbon, 46(3), 1261-1271.

Luo, Y. Q. (2003), Uncertainties in interpretation of isotope signals for estimation of fine root longevity: theoretical considerations, Glob Change Biol, 9(7), 1118-1129. 
Majdi, H. (2005), Fine root turnover in forest ecosystems - Preface, Plant And Soil, 276(1-2), VIIVIII.

Matamala, R., M. A. Gonzalez-Meler, J. D. Jastrow, R. J. Norby, and W. H. Schlesinger (2003), Impacts of fine root turnover on forest NPP and soil C sequestration potential, Science, 302(5649), 1385-1387.

McClaugherty, C. A., J. D. Aber, and J. M. Melillo (1982), The Role of Fine Roots in the Organic Matter and Nitrogen Budgets of Two Forested Ecosystems, Ecology, 63(5), 1481-1490.

Ostertag, R. (2001), Effects of nitrogen and phosphorus availability on fine-root dynamics in Hawaiian montane forests, Ecology, 82(2), 485-499.

Parton, W. J., M. Hartman, D. Ojima, and D. Schimel (1998), DAYCENT and its land surface submodel: description and testing, Global And Planetary Change, 19(1-4), 35-48.

Pregitzer, K. S. (2002), Fine roots of trees - a new perspective, New Phytol, 154(2), 267-270.

Pregitzer, K. S. (2003), Woody plants, carbon allocation and fine roots, New Phytol, 158(3), 421424.

Pregitzer, K. S., M. J. Laskowski, A. J. Burton, V. C. Lessard, and D. R. Zak (1998), Variation in sugar maple root respiration with root diameter and soil depth, Tree Physiol, 18(10), 665-670.

Pregitzer, K. S., J. L. DeForest, A. J. Burton, M. F. Allen, R. W. Ruess, and R. L. Hendrick (2002), Fine root architecture of nine North American trees, Ecol Monogr, V72(N2), 293-309.

Press, W., B. Flannery, S. Teukolsky, and W. Vetterling (1989), Numerical Recipes (FORTRAN), 702 pp., Cambridge Univ. Press.

Pritchard, S. G., and A. E. Strand (2008), Can you believe what you see? Reconciling minirhizotron and isotopically derived estimates of fine root longevity, New Phytol, 177(2), 287-291.

Riley, W. J., J. B. Gaudinski, M. S. Torn, T. E. Dawson, J. D. Joslin, and H. Majdi (2009), FineRoot Mortality Rates in a Temperate Forest: Estimates using Radiocarbon Data and Numerical Modeling, New Phytol, 184(2), 387-398.

Rodhe, H. (Ed.) (1992), Modeling Biogeochemical Cycles, 55-72 pp., Academic Press, San Diego, CA.

Schuur, E. A. G., and S. E. Trumbore (2006), Partitioning sources of soil respiration in boreal black spruce forest using radiocarbon, Glob Change Biol, 12(2), 165-176.

Sternberg, L. D. L., M. J. Deniro, and R. A. Savidge (1986), Oxygen Isotope Exchange Between Metabolites And Water During Biochemical Reactions Leading To Cellulose Synthesis, Plant Physiology, 82(2), 423-427.

Strand, A. E., S. G. Pritchard, M. L. McCormack, M. A. Davis, and R. Oren (2008), Irreconcilable differences: Fine-root life spans and soil carbon persistence, Science, 319(5862), 456-458.

Stuiver, M., and H. A. Polach (1977), Reporting Of C-14 Data - Discussion, Radiocarbon, 19(3), 355-363.

Thornton, P. E., J. F. Lamarque, N. A. Rosenbloom, and N. M. Mahowald (2007), Influence of carbon-nitrogen cycle coupling on land model response to $\mathrm{CO} 2$ fertilization and climate variability, Glob. Biogeochem. Cycle, 21(4).

Tierney, G. L., and T. J. Fahey (2002), Fine root turnover in a northern hardwood forest: a direct comparison of the radiocarbon and minirhizotron methods, Canadian Journal of Forest ResearchJournal Canadien de la Recherche Forestiere, 32(9), 1692-1697.

Trumbore, S., E. S. Da Costa, D. C. Nepstad, P. B. De Camargo, L. Martinelli, D. Ray, T. Restom, and W. Silver (2006), Dynamics of fine root carbon in Amazonian tropical ecosystems and the contribution of roots to soil respiration, Glob Change Biol, 12(2), 217-229. 
Trumbore, S. E., and J. B. Gaudinski (2003), The secret lives of roots, Science, 302(5649), 13441345.

Vargas, R., S. E. Trumbore, and M. F. Allen (2009), Evidence of old carbon used to grow new fine roots in a tropical forest, New Phytol, 182(3), 710-718.

Vogt, K. A., and H. Persson (Eds.) (1991), Measuring growth and developement of roots., CRC

Press, Boca, Raton, Florida.

Wang, Z. Q., D. L. Guo, X. R. Wang, J. C. Gu, and L. Mei (2006), Fine root architecture, morphology, and biomass of different branch orders of two Chinese temperate tree species, Plant And Soil, 288(1-2), 155-171.

Wells, C. E., and D. M. Eissenstat (2001), Marked differences in survivorship among apple roots of different diameters, Ecology, 82(3), 882-892.

Wells, C. E., and D. M. Eissenstat (2003), Beyond the roots of young seedlings: The influence of age and order on fine root physiology, Journal Of Plant Growth Regulation, 21(4), 324-334.

Wells, C. E., D. M. Glenn, and D. M. Eissenstat (2002), Changes in the risk of fine-root mortality with age: A case study in peach, Prunus persica (Rosaceae), American Journal Of Botany, 89(1), 79-87.

Widen, B., and H. Majdi (2001), Soil CO2 efflux and root respiration at three sites in a mixed pine and spruce forest: seasonal and diurnal variation, Canadian Journal Of Forest Research-Revue Canadienne De Recherche Forestiere, 31(5), 786-796.

Withington, J. M., P. B. Reich, J. Oleksyn, and D. M. Eissenstat (2006), Comparisons of structure and life span in roots and leaves among temperate trees, Ecol Monogr, 76(3), 381-397. 


\section{DISCLAIMER}

This document was prepared as an account of work sponsored by the United States Government. While this document is believed to contain correct information, neither the United States Government nor any agency thereof, nor the Regents of the University of California, nor any of their employees, makes any warranty, express or implied, or assumes any legal responsibility for the accuracy, completeness, or usefulness of any information, apparatus, product, or process disclosed, or represents that its use would not infringe privately owned rights. Reference herein to any specific commercial product, process, or service by its trade name, trademark, manufacturer, or otherwise, does not necessarily constitute or imply its endorsement, recommendation, or favoring by the United States Government or any agency thereof, or the Regents of the University of California. The views and opinions of authors expressed herein do not necessarily state or reflect those of the United States Government or any agency thereof or the Regents of the University of California. 